\title{
International Trade and Macroeconomic Dynamics with Heterogeneous Firms
}

\section{Citation}

Ghironi, Fabio, and Marc J. Melitz. 2005. International trade and macroeconomic dynamics with heterogeneous firms. Quarterly Journal of Economics 120, no. 3: 865-915.

\section{Published Version}

http://dx.doi.org/10.1162/003355305774268246

\section{Permanent link}

http://nrs.harvard.edu/urn-3:HUL.InstRepos:3228377

\section{Terms of Use}

This article was downloaded from Harvard University's DASH repository, and is made available under the terms and conditions applicable to Other Posted Material, as set forth at http:// nrs.harvard.edu/urn-3:HUL.InstRepos:dash.current.terms-of-use\#LAA

\section{Share Your Story}

The Harvard community has made this article openly available.

Please share how this access benefits you. Submit a story.

\section{Accessibility}




\title{
INTERNATIONAL TRADE AND MACROECONOMIC DYNAMICS WITH HETEROGENEOUS FIRMS*
}

\author{
Fabio Ghironi and Marc J. Melitz
}

\begin{abstract}
We develop a stochastic, general equilibrium, two-country model of trade and macroeconomic dynamics. Productivity differs across individual, monopolistically competitive firms in each country. Firms face a sunk entry cost in the domestic market and both fixed and per-unit export costs. Only relatively more productive firms export. Exogenous shocks to aggregate productivity and entry or trade costs induce firms to enter and exit both their domestic and export markets, thus altering the composition of consumption baskets across countries over time. In a world of flexible prices, our model generates endogenously persistent deviations from PPP that would not exist absent our microeconomic structure with heterogeneous firms. It provides an endogenous, microfounded explanation for a HarrodBalassa-Samuelson effect in response to aggregate productivity differentials and deregulation. Finally, the model successfully matches several moments of U. S. and international business cycles.
\end{abstract}

\section{INTRODUCTION}

Formal models of international macroeconomic dynamics do not usually address or incorporate the determinants and evolution of trade patterns. The vast majority of such macroeconomic models take the pattern of international trade and the structure of markets for goods and factors of production as given. ${ }^{1}$ The determinants of such trade patterns are, in turn, analyzed within methodologically distinct models that are generally limited to comparisons of long-run positions or growth dynamics after changes in some determinants of trade. These models do not consider short- to medium-run business cycle dynamics and their effect on the pattern of trade over time. This separation between modern models of international macroeconomics and trade theory

\footnotetext{
* For helpful comments, we thank the editor (Robert Barro), two anonymous referees, Philippe Bacchetta, Marianne Baxter, Paul Bergin, Lawrence Christiano, Giancarlo Corsetti, Jonathan Eaton, Pierre-Olivier Gourinchas, Gene Grossman, Elhanan Helpman, Hugo Hopenhayn, Andreas Hornstein, Jean Imbs, Paolo Pesenti, Kenneth Rogoff, Kei-Mu Yi, and seminar and conference participants at several institutions. We are grateful to Kolver Hernandez for excellent research assistance. Remaining errors are our responsibility. We thank the NSF for financial support (SES 0417757). Ghironi also acknowledges funding for this project from Boston College and the European University Institute, through a Jean Monnet Fellowship in the General Programme of the Robert Schuman Centre for Advanced Studies.

1. See Lane [2001] for a survey of the recent literature. We discuss the relation between our work and some exceptions to this trend in international macroeconomics below.

$\odot 2005$ by the President and Fellows of Harvard College and the Massachusetts Institute of Technology.

The Quarterly Journal of Economics, August 2005
} 
is somewhat unnatural. Modern international macroeconomics prides itself on its microfoundations. Yet, it neglects to analyze the effects of macro phenomena on its microeconomic underpinnings. Similarly, much of trade theory does not recognize the aggregate feedback effects of micro-level adjustments over time. ${ }^{2}$

This paper contributes to bridging the gap between international macroeconomics and trade theory. We use Melitz's [2003] model of trade with monopolistic competition and heterogeneous firms as the microeconomic underpinning of a two-country, dynamic, stochastic, general equilibrium (DSGE) model of international trade and macroeconomics. ${ }^{3}$ Firms face some initial uncertainty concerning their future productivity when making an irreversible investment to enter the domestic market. Postentry, firms produce with different productivity levels. In addition to the sunk entry cost, firms face both fixed and per-unit export costs. ${ }^{4}$ Forward-looking firms formulate entry and export decisions based on expectations of future market conditions. Only a subset of relatively more productive firms export, while the remaining, less productive firms only serve their domestic market. This microeconomic structure endogenously determines the extent of the traded sector and the composition of consumption baskets in both countries. Exogenous shocks to aggregate productivity, or entry and trade costs induce firms to enter and exit both their domestic and export markets, thus altering the composition of consumption baskets across countries over time. This introduces a new and potentially important channel for the transmission of macroeconomic shocks and their propagation over time.

We first introduce this microeconomic structure in a flexibleprice model with no international trade in financial assets-and focus on the role of goods market dynamics. We show that the microeconomic features of our model have important consequences for macroeconomic variables. Macroeconomic dynamics,

2. Baldwin and Lyons [1994] and Dumas [1992] are two notable exceptions. They analyze general equilibrium models that describe the dynamic interactions between costly trade and the real exchange rate. We incorporate microfoundations into such a model.

3. Melitz [2003] focuses on the analysis of steady-state effects of trade.

4. Recent empirical micro-level studies have documented the relevance of plant-level fixed export costs. See Bernard and Jensen [2001] (for the United States), Bernard and Wagner [2001] (for Germany), Das, Roberts, and Tybout [2001] (for Colombia), and Roberts and Tybout [1997] (for Colombia). These fixed costs include market research, advertising, and regulatory (such as testing, packaging, labeling requirements) expenses incurred by plants exporting differentiated products. 
in turn, feed back into firm-level decisions, further altering the pattern of trade over time. Our model generates deviations from purchasing power parity (PPP) that would not exist absent our microeconomic structure with heterogeneous firms. It provides an endogenous, microfounded explanation for a Harrod-BalassaSamuelson (HBS) effect: More productive economies, or less regulated ones (phenomena that affect all firms in the economy), exhibit higher average prices relative to their trading partners. We then show how, under fully flexible prices, deviations from PPP display substantial endogenous persistence in response to transitory aggregate shocks (for very plausible calibrated parameters). ${ }^{5}$ Since the micro-level adjustments we analyze occur within sectors, our model also explains how these deviations from PPP are manifested in sector-level prices-even for sectors considered "traded."

Next, we extend our model to allow for international bond trading. In this setup, we show that permanently more productive economies, or less regulated ones, also run persistent foreign debt positions to finance the accelerated entry of firms into the relatively more favorable business environment. A stochastic exercise shows that the model matches several important moments of the U. S. and international business cycle quite well. In contrast to benchmark international real business cycle (RBC) models, our setup generates positive GDP correlation across countries; it does not automatically produce high correlation between relative consumption and the real exchange rate; and it substantially reduces the "consumption-output anomaly" associated with standard models.

The rest of the paper is organized as follows. Section II discusses the HBS effect and contrasts our approach to the related literature. Section III describes the benchmark model with financial autarky. Section IV presents results on the determinants of the real exchange rate in our setup. These results guide our interpretation of the impulse responses in Section V, which analyzes the dynamic responses to shocks affecting aggregate productivity and sunk entry costs (interpreted as changes in domestic market regulation). Section VI introduces international bond trading and discusses its implications. It also presents re-

5. More generally, the introduction of micro dynamics motivated by heterogeneity, and entry and trade costs, significantly improves the ability of our model to generate endogenously persistent dynamics: a stumbling block for many wellknown DSGE macro models. 
sults on second-moment properties of the model. Section VII concludes.

\section{The HBS Literature And our Modeling Approach}

Textbook analysis of the HBS effect assumes an exogenously defined nontraded sector and some favorable productivity shocks affecting only the traded sector. These shocks cause the relative price of nontraded goods to increase, leading to a real exchange rate appreciation (relative to trading partners). An aggregate productivity increase (across all sectors) would have no effect on the real exchange rate. Although the cross-country correlation between development (usually measured as GDP per capita) and price levels is robust and pervasive, the evidence linking this correlation to productivity differentials across traded and nontraded sectors is much weaker and controversial (see Rogoff [1996, sections 6A-B]). Our model explains the former without relying on the latter; it also explains why persistent deviations from PPP also show up in cross-country price differences for tradable goods as documented by Engel [1993, 1999].

One potential problem with the textbook HBS effect is the reliance on the law of one price for traded goods. If these are differentiated, then productivity shocks to either the traded or nontraded sectors engender movements in the terms of trade across countries. Recently, Fitzgerald [2003] and MacDonald and Ricci [2002] have shown how product differentiation within tradables affects the measurement of HBS, and have found indirect evidence for such terms-of-trade effects. Our model incorporates these effects, but additionally addresses a more fundamental inconsistency with the textbook HBS effect highlighted by recent micro-level studies of plant export behavior: most goods in the tradable sector are not traded. Moreover, this division between traded and nontraded occurs within narrowly defined sectors (on the demand side) and substantially evolves over time. For example, in the United States, only 21 percent of manufacturing plants export [Bernard, Eaton, Jensen, and Kortum 2003], and roughly 13 percent of plants switch their export status in a given year [Bernard and Jensen 2004]. ${ }^{6}$ It therefore seems improbable-as

6. Similar patterns hold for many other countries. Bernard et al. [2003] further report that the partitioning between exporters and nonexporters is pervasive across narrowly defined four-digit manufacturing sectors. Bernard and 
required for the "textbook" HBS effect—-that some productivity shocks only affect the (time varying) proportion of exporting firms within each sector.

Our model captures the effects of aggregate shocks on both the determination of the set of traded goods and their terms of trade. As previously mentioned, these changes occur within sectors and generate persistent deviations in sector-level prices. Although we do not explicitly model multiple sectors, our framework nevertheless highlights the micro-level characteristics of sectors (the level of product differentiation, firm entry and exit rates, levels of sunk costs and trade costs) that would generate differences in persistence rates for cross-country sector-level price differentials. Imbs, Mumtaz, Ravn, and Rey [2005] and Cheung, Chinn, and Fujii [2001] both document that sector-level price differentials can be very persistent (across countries), and that the persistence levels are quite heterogeneous across sectors. Cheung, Chinn, and Fujii further find that sectors with more intraindustry trade exhibit higher persistence levels-a finding that is broadly consistent with the forces in our model.

Dornbusch, Fischer, and Samuelson [DFS 1977] first analyzed the endogenous determination of nontraded sectors, and pointed out how aggregate productivity shocks could lead to average price differentials across countries. Bergin and Glick [2003a, 2003b] embed this structure into a dynamic framework where endogenous nontradability further arises from differences in trade costs across sectors. ${ }^{7}$ Whereas this line of research analyzes cross-sectoral variations in tradability, we focus on the within-sector determination of "tradedness" based on firm-level decisions: all goods are tradable in our model; some are nontraded as a consequence of firm decisions. We believe that the endogenous determination of both intrasectoral nontradedness and intersectoral nontradability are important, and we view these lines of research as complementary.

Other contributions to the international macroeconomic literature have emphasized the role of trade costs and nontraded intermediate services in the propagation of shocks. Already

Jensen [2004] also document the important aggregate effects of new exporters: in the United States, 38 percent of the export growth between 1987 and 1992 was driven by entry of new exporters.

7. Obstfeld and Rogoff [1996, Ch. 4], Kehoe and Ruhl [2002], and Kraay and Ventura [2002] also develop dynamic extensions of the DFS model that capture changes in the pattern of trade (and tradability) over time. 
Backus, Kehoe, and Kydland [1992] showed that the inclusion of trade frictions improves the quantitative performance of an international RBC model. Obstfeld and Rogoff [2001] present simple models in which the addition of per-unit trade costs and the potentially endogenous nature of tradedness help explain a number of puzzles in international macroeconomics. Burstein, Neves, and Rebelo [2003] and Burstein, Eichenbaum, and Rebelo [2002] focus on the role of the nontraded distribution sector and composition effects in the CPI.

Several recent papers study the consequences of firm entry or endogenous nontradedness. Ricci [1997] focuses on the effect of the exchange rate regime on the location choice of monopolistically competitive firms under sticky prices and wages. Corsetti, Martin, and Pesenti [2005] explore the implications of entry for the transmission of monetary shocks in a two-country, stickywage model in which all goods are traded. Bergin, Glick, and Taylor [2003] use a model with monopolistic competition, fixed export costs, and heterogeneous productivity (but an exogenous number of producers) in their analysis of the HBS effect. Betts and Kehoe [2001] introduce heterogeneous, per-unit trade costs in a multicountry, trade and macro model with complete asset markets and differentiated goods. Our approach is distinguished by its focus on fixed costs, heterogeneous productivity, and endogenous entry into both domestic and export markets. ${ }^{8}$

\section{THe Model}

We begin by developing a version of our model under financial autarky.

\section{III.A. Household Preferences and Intratemporal Choices}

The world consists of two countries, home and foreign. We denote foreign variables by an asterisk. Each country is populated by a unit mass of atomistic households. All contracts and prices in the world economy are written in nominal terms. Prices are flexible. Thus, we only solve for the real variables in the model. However, as the composition of consumption baskets in

8. Alessandria and Choi [2003], Ruhl [2003], and Russ [2003] develop models that are closest to ours. In contrast to our model, Alessandria and Choi assume that firm-specific productivity displays no persistence; Ruhl uses a model that includes an exogenously nontraded good; and Russ focuses on foreign direct investment under nominal stickiness. 
the two countries changes over time (affecting the definitions of the consumption-based price indexes), we introduce money as a convenient unit of account for contracts. Money plays no other role in the economy. For this reason, we do not model the demand for cash currency, and resort to a cashless economy as in Woodford [2003].

The representative home household supplies $L$ units of labor inelastically in each period at the nominal wage rate $W_{t}$, denominated in units of home currency. The household maximizes expected intertemporal utility from consumption $(C): E_{t}\left[\sum_{s=t}^{\infty}\right.$ $\left.\beta^{s-t} C_{s}^{1-\gamma} /(1-\gamma)\right]$, where $\beta \in(0,1)$ is the subjective discount factor and $\gamma>0$ is the inverse of the intertemporal elasticity of substitution. At time $t$, the household consumes the basket of goods $C_{t}$, defined over a continuum of goods $\Omega: C_{t}=\left(\int_{\omega \in \Omega}\right.$ $\left.c_{t}(\omega)^{(\theta-1) / \theta} d \omega\right)^{\theta /(\theta-1)}$, where $\theta>1$ is the symmetric elasticity of substitution across goods. At any given time $t$, only a subset of goods $\Omega_{t} \subset \Omega$ is available. Let $p_{t}(\omega)$ denote the home currency price of a good $\omega \in \Omega_{t}$. The consumption-based price index for the home economy is then $P_{t}=\left(\int_{\omega \in \Omega_{t}} p_{t}(\omega)^{1-\theta} d \omega\right)^{1 /(1-\theta)}$, and the household's demand for each individual good $\omega$ is $c_{t}(\omega)=$ $\left(p_{t}(\omega) / P_{t}\right)^{-\theta} C_{t}$.

The foreign household supplies $L^{*}$ units of labor inelastically in each period in the foreign labor market at the nominal wage rate $W_{t}^{*}$, denominated in units of foreign currency. It maximizes a similar utility function, with identical parameters and a similarly defined consumption basket. Crucially, the subset of goods available for consumption in the foreign economy during period $t$ is $\Omega_{t}^{*} \subset \Omega$ and can differ from the subset of goods that are available in the home economy.

\section{III.B. Production, Pricing, and the Export Decision}

There is a continuum of firms in each country, each producing a different variety $\omega \in \Omega$. Production requires only one factor, labor. Aggregate labor productivity is indexed by $Z_{t}\left(Z_{t}^{*}\right)$, which represents the effectiveness of one unit of home (foreign) labor. Firms are heterogeneous as they produce with different technologies indexed by relative productivity $z$. A home firm with relative productivity $z$ produces $Z_{t} z$ units of output per unit of labor employed. Productivity differences across firms therefore translate into differences in the unit cost of production. This cost, measured in units of the consumption good $C_{t}$, is $w_{t} /\left(Z_{t} z\right)$, where $w_{t} \equiv W_{t} / P_{t}$ is the real wage. Similarly, foreign firms are indexed 
by their productivity $z$ and unit cost (measured in units of the foreign consumption good) $w_{t}^{*} /\left(Z_{t}^{*} z\right)$, where $w_{t}^{*} \equiv W_{t}^{*} / P_{t}^{*}$ is the real wage of foreign workers. ${ }^{9}$

Prior to entry, firms are identical and face a sunk entry cost of $f_{E, t}\left(f_{E, t}^{*}\right)$ effective labor units, equal to $w_{t} f_{E, t} / Z_{t}\left(w_{t}^{*} f_{E, t}^{*} / Z_{t}^{*}\right)$ units of the home (foreign) consumption good. Upon entry, home firms draw their productivity level $z$ from a common distribution $G(z)$ with support on $\left[z_{\text {min }}, \infty\right)$. Foreign firms draw their productivity level from an identical distribution. This relative productivity level remains fixed thereafter. Since there are no fixed production costs, all firms produce in every period, until they are hit with a "death" shock, which occurs with probability $\delta \in(0,1)$ in every period. This exit-inducing shock is independent of the firm's productivity level, so $G(z)$ also represents the productivity distribution of all producing firms.

Given our modeling assumption relating each firm to an individual variety, we think of a firm as a production line for that variety, and the entry cost as the development and setup cost associated with the latter (potentially influenced by market regulation). The exogenous "death" shock also takes place at the individual variety level. Empirically, a firm may comprise more than one of these production lines. Our model does not address the determination of product variety within firms, but our main results would be unaffected by the introduction of multiproduct firms.

Home and foreign firms can serve both their domestic market as well as the export market. Exporting is costly, and involves both a melting-iceberg trade $\operatorname{cost} \tau_{t} \geq 1\left(\tau_{t}^{*} \geq 1\right)$ as well as a fixed $\operatorname{cost} f_{X, t}\left(f_{X, t}^{*}\right)$ (measured in units of effective labor). We assume that firms hire workers from their respective domestic labor markets to cover these fixed costs. These costs, in real terms, are then $w_{t} f_{X, t} / Z_{t}$ for home firms (in units of the home consumption good) and $w_{t}^{*} f_{X, t}^{*} / Z_{t}^{*}$ for foreign firms (in units of the foreign consumption good). The fixed export costs are paid on a period-

9. We use the same index $z$ for both home and foreign firms as this variable only captures firm productivity relative to the distribution of firms in that country. Consistent with standard RBC theory, aggregate productivity $Z_{t}\left(Z_{t}^{*}\right)$ affects all home (foreign) labor uniformly. We abstract from more complex technology diffusion processes across firms of different vintages. See Caballero and Hammour [1994] and Campbell [1998] for a treatment of this topic. 
by-period basis rather than sunk upon entry in the export market. ${ }^{10}$

All firms face a residual demand curve with constant elasticity $\theta$ in both markets, and they set flexible prices that reflect the same proportional markup $\theta /(\theta-1)$ over marginal cost. Let $p_{D, t}(z)$ and $p_{X, t}(z)$ denote the nominal domestic and export prices of a home firm. We assume that export prices are denominated in the currency of the export market. Prices, in real terms relative to the price index in the destination market, are then given by

$$
\rho_{D, t}(z) \equiv \frac{p_{D, t}(z)}{P_{t}}=\frac{\theta}{\theta-1} \frac{w_{t}}{Z_{t} z}, \quad \rho_{X, t}(z) \equiv \frac{p_{X, t}(z)}{P_{t}^{*}}=Q_{t}^{-1} \tau_{t} \rho_{D, t}(z),
$$

where $Q_{t} \equiv \varepsilon_{t} P_{t}^{*} / P_{t}$ is the consumption-based real exchange rate (units of home consumption per unit of foreign consumption; $\varepsilon_{t}$ is the nominal exchange rate, units of home currency per unit of foreign) ${ }^{11}$ However, due to the fixed export cost, firms with low productivity levels $z$ may decide not to export in any given period. When making this decision, a firm decomposes its total profit $d_{t}(z)\left(d_{t}^{*}(z)\right)$ (returned to households as dividends) into portions earned from domestic sales $d_{D, t}(z)\left(d_{D, t}^{*}(z)\right)$ and from potential export sales $d_{X, t}(z)\left(d_{X, t}^{*}(z)\right)$. All these profit levels (dividends) are expressed in real terms in units of the consumption basket in the firm's location. ${ }^{12}$ In the case of a home firm, total profits in period $t$ are given by $d_{t}(z)=d_{D, t}(z)+d_{X, t}(z)$, where

$$
\begin{aligned}
& d_{D, t}(z)=\frac{1}{\theta}\left[\rho_{D, t}(z)\right]^{1-\theta} C_{t}, \\
& d_{X, t}(z)= \begin{cases}\frac{Q_{t}}{\theta}\left[\rho_{X, t}(z)\right]^{1-\theta} C_{t}^{*}-\frac{w_{t} f_{X, t}}{Z_{t}} & \text { if firm } z \text { exports, } \\
0 & \text { otherwise. }\end{cases}
\end{aligned}
$$

10. Although a substantial portion of fixed export costs are probably sunk upon market entry, we do not model the sunk nature of these costs explicitly. We do this for simplicity, as sunk export market entry costs would complicate the solution method considerably while leaving the main message of the paper unaffected. We conjecture that introducing these costs would enhance the persistence properties of our model.

11. Similar price equations hold for foreign firms. Note that $\rho_{X, t}^{*}(z) \equiv p_{X, t}^{*}(z) /$ $P_{t}=Q_{t} \tau_{t}^{*} \rho_{D, t}^{*}(z)$.

12. Note that an exporter's relative price $\rho_{X, t}(z)\left(\rho_{X, t}^{*}(z)\right)$ is expressed in units of $C_{t}^{*}\left(C_{t}\right)$ (the consumption good at the location of sales) but the profits from export sales $d_{X, t}(z)\left(d_{X, t}^{*}(z)\right)$ are expressed in units of $C_{t}\left(C_{t}^{*}\right)$ (the consumption basket in the firm's location). 
Foreign firms behave in a similar way. ${ }^{13}$ As expected, more productive firms earn higher profits (relative to less productive firms), although they set lower prices (see (1)). ${ }^{14}$ A firm will export if and only if it would earn nonnegative profit from doing so. For home firms, this will be the case so long as productivity $z$ is above a cutoff level $z_{X, t}=\inf \left\{z: d_{X, t}(z)>0\right\}$. A similar cutoff level $z_{X, t}^{*}=\inf \left\{z: d_{X, t}^{*}(z)>0\right\}$ holds for foreign exporters. We assume that the lower bound productivity $z_{\min }$ is low enough relative to the export costs that $z_{X, t}$ and $z_{X, t}^{*}$ are both above $z_{\text {min }}$. This ensures the existence of an endogenously determined nontraded sector: the set of firms that could export, but decide not to. These firms, with productivity levels between $z_{\min }$ and the export cutoff level, only produce for their domestic market. This set of firms fluctuates over time with changes in the profitability of the export market, inducing changes in the cutoff levels $z_{X, t}$ and $z_{X, t}^{*}$.

\section{III.C. Firm Averages}

In every period, a mass $N_{D, t}\left(N_{D, t}^{*}\right)$ of firms produces in the home (foreign) country. These firms have a distribution of productivity levels over $\left[z_{\min }, \infty\right)$ given by $G(z)$. Among these firms, there are $N_{X, t}=\left[1-G\left(z_{X, t}\right)\right] N_{D, t}$ and $N_{X, t}^{*}=\left[1-G\left(z_{X, t}^{*}\right)\right] N_{D, t}^{*}$ exporters. Following Melitz [2003], we define two special "average" productivity levels - an average $\tilde{z}_{D}$ for all producing firms (in each country), and an average $\tilde{z}_{X, t}$ for all home exporters:

$\tilde{z}_{D} \equiv\left[\int_{z_{\min }}^{\infty} z^{\theta-1} d G(z)\right]^{1 /(\theta-1)}, \quad \tilde{z}_{X, t} \equiv\left[\frac{1}{1-G\left(z_{X, t}\right)} \int_{z_{X, t}}^{\infty} z^{\theta-1} d G(z)\right]^{1 /(\theta-1)}$.

(The definition of $\tilde{z}_{X, t}^{*}$ is analogous to that of $\tilde{z}_{X, t}$.) As shown in Melitz, these productivity averages-based on weights proportional to relative firm output shares-summarize all the information on the productivity distributions relevant for all macroeconomic variables. In essence, our model is isomorphic to one where $N_{D, t}\left(N_{D, t}^{*}\right)$ firms with productivity level $\tilde{z}_{D}$ produce in the home (foreign) country and $N_{X, t}\left(N_{X, t}^{*}\right)$ firms with productivity level $\tilde{z}_{X, t}$ $\left(\tilde{z}_{X, t}^{*}\right)$ export to the foreign (home) market.

13. A foreign firm earns export profits $d_{X, t}^{*}(z)=Q_{t}^{-1}\left[\rho_{X, t}^{*}(z)\right]{ }^{1-\theta} C_{t} / \theta-$ $w_{t}^{*} f_{X, t}^{*}, Z_{t}^{*}$ if it sells output in the home country.

14 . We think of firm prices as adjusted for product quality. Our model is isomorphic to one where firms produce the differentiated goods with different quality levels. 
In particular, $\tilde{p}_{D, t} \equiv p_{D, t}\left(\tilde{z}_{D}\right)\left(\tilde{p}_{D, t}^{*} \equiv p_{D, t}^{*}\left(\tilde{z}_{D}\right)\right)$ represents the average nominal price of home (foreign) firms in their domestic market, and $\tilde{p}_{X, t} \equiv p_{X, t}\left(\tilde{z}_{X, t}\right)\left(\tilde{p}_{X, t}^{*} \equiv p_{X, t}^{*}\left(\tilde{z}_{X, t}^{*}\right)\right)$ represents the average nominal price of home (foreign) exporters in the export market. The price index at home therefore reflects the prices of the $N_{D, t}$ home firms (with average price $\tilde{p}_{D, t}$ ) and the $N_{X, t}^{*}$ foreign exporters to the home market (with average price $\tilde{p}_{X, t}^{*}$ ). The home price index can thus be written as $P_{t}=$ $\left[N_{D, t}\left(\tilde{p}_{D, t}\right)^{1-\theta}+N_{X, t}^{*}\left(\tilde{p}_{X, t}^{*}\right)^{1-\theta}\right]^{1 /(1-\theta)}$. This is equivalent to $N_{D, t}\left(\tilde{\rho}_{D, t}\right)^{1-\theta}+N_{X, t}^{*}\left(\tilde{\rho}_{X, t}^{*}\right)^{1^{-}-\theta}=1$, where $\tilde{\rho}_{D, t} \equiv \rho_{D, t}\left(\tilde{z}_{D}\right)$ and $\tilde{\rho}_{X, t}^{*} \equiv \rho_{X, t}^{*}\left(\tilde{z}_{X, t}^{*}\right)$ represent the average relative prices of home producers and foreign exporters in the home market. Similar equations hold for the foreign price index.

The productivity averages $\tilde{z}_{D}, \tilde{z}_{X, t}$, and $\tilde{z}_{X, t}^{*}$ are constructed in such a way that $\tilde{d}_{D, t} \equiv d_{D, t}\left(\tilde{z}_{D}\right)\left(\tilde{d}_{D, t}^{*} \equiv d_{D, t}^{*}\left(\tilde{z}_{D}\right)\right)$ represents the average firm profit earned from domestic sales for all home (foreign) producers; and $\tilde{d}_{X, t} \equiv d_{X, t}\left(\tilde{z}_{X, t}\right)\left(\tilde{d}_{X, t}^{*} \equiv d_{X, t}^{*}\left(\tilde{z}_{X, t}^{*}\right)\right)$ represents the average firm export profits for all home (foreign) exporters. Thus, $\tilde{d}_{t} \equiv \tilde{d}_{D, t}+\left[1-G\left(z_{X, t}\right)\right] \tilde{d}_{X, t}$ and $\tilde{d}_{t}^{*} \equiv \tilde{d}_{D, t}^{*}+$ $\left[1-G\left(z_{X, t}^{*}\right)\right] \tilde{d}_{X, t}^{*}$ represent the average total profits of home and foreign firms, since $1-G\left(z_{X, t}\right)$ and $1-G\left(z_{X, t}^{*}\right)$ represent the proportion of home and foreign firms that export and earn export profits. $^{15}$

\section{III.D. Firm Entry and Exit}

In every period there is an unbounded mass of prospective entrants in both countries. These entrants are forward looking, and correctly anticipate their future expected profits $\tilde{d}_{t}\left(\tilde{d}_{t}^{*}\right)$ in every period (the preentry expected profit is equal to postentry average profit) as well as the probability $\delta$ (in every period) of incurring the exit-inducing shock. We assume that entrants at time $t$ only start producing at time $t+1$, which introduces a one-period time-to-build lag in the model. The exogenous exit shock occurs at the very end of the time period (after production and entry). A proportion $\delta$ of new entrants will therefore never produce. Prospective home entrants in period $t$ compute their expected postentry value given by the present discounted value of their expected stream of profits $\left\{\tilde{d}_{s}\right\}_{s=t+1}^{\infty}$ :

15. $\tilde{d}_{t}$ and $\tilde{d}_{t}^{*}$ represent average firm profit levels in the sense that $\tilde{d}_{t}=\int_{z_{\min }}^{\infty}$ $d_{t}(z) d G(z)$ and $\tilde{d}_{t}^{*}=\int_{z_{\min }}^{\infty} d_{t}^{*}(z) d G(z)$. See Melitz [2003] for proofs. 


$$
\tilde{v}_{t}=E_{t} \sum_{s=t+1}^{\infty}[\beta(1-\delta)]^{s-t}\left(\frac{C_{s}}{C_{t}}\right)^{-\gamma} \tilde{d}_{s}
$$

This also represents the average value of incumbent firms after production has occurred (since both new entrants and incumbents then face the same probability $1-\delta$ of survival and production in the subsequent period). Firms discount future profits using the household's stochastic discount factor, adjusted for the probability of firm survival $1-\delta$. Entry occurs until the average firm value is equalized with the entry cost, leading to the free entry condition $\tilde{v}_{t}=w_{t} f_{E, t} / Z_{t}$. This condition holds so long as the mass $N_{E, t}$ of entrants is positive. We assume that macroeconomic shocks are small enough for this condition to hold in every period. Finally, the timing of entry and production we have assumed implies that the number of home-producing firms during period $t$ is given by $N_{D, t}=$ $(1-\delta)\left(N_{D, t-1}+N_{E, t-1}\right)$. Similar free entry condition, requirement on the size of shocks, and law of motion for the number of producing firms hold in the foreign country.

\section{III.E. Parameterization of Productivity Draws}

In order to solve our model, we parameterize the distribution of firm productivity draws $G(z)$. We assume that productivity $z$ is distributed Pareto with lower bound $z_{\min }$ and shape parameter $k>\theta-1: G(z)=1-\left(z_{\min } / z\right)^{k}$. The assumption of a Pareto distribution for productivity induces a size distribution of firms that is also Pareto, which fits firm-level data quite well. $k$ indexes the dispersion of productivity draws: dispersion decreases as $k$ increases, and the firm productivity levels are increasingly concentrated toward their lower bound $z_{\min }{ }^{16}$ Letting $v \equiv\{k /[k-$ $(\theta-1)]\}^{1 /(\theta-1)}$, the average productivities $\tilde{z}_{D}$ and $\tilde{z}_{X, t}$ are given by $\tilde{z}_{D}=v z_{\min }$ and $\tilde{z}_{X, t}=v z_{X, t}$. The share of home-exporting firms is then $N_{X, t} / N_{D, t}=1-G\left(z_{X, t}\right)=\left(\nu z_{\text {min }} / \tilde{z}_{X, t}\right)^{k}$, and the zero export profit condition (for the cutoff firm), $d_{X, t}\left(z_{X, t}\right)=0$, implies that average export profits must satisfy $\tilde{d}_{X, t}=(\theta-1)\left(v^{\theta-1} /\right.$ $k) w_{t} f_{X, t} / Z_{t}$. Analogous results hold for $\tilde{z}_{X, t}^{*}, N_{X, t}^{*} / N_{D, t}^{*}$, and $\tilde{d}_{X, t}^{*}$.

16. The standard deviation of log productivity is equal to $1 / k$. The condition that $k>\theta-1$ ensures that the variance of firm size is finite. 


\section{III.F. Household Budget Constraint and Intertemporal Choices}

Households in each country hold two types of assets: shares in a mutual fund of domestic firms and domestic, risk-free bonds. (We assume that bonds pay risk-free, consumption-based real returns.) We now focus on the home economy. Let $x_{t}$ be the share in the mutual fund of home firms held by the representative home household entering period $t$. The mutual fund pays a total profit in each period (in units of home currency) that is equal to the average total profit of all home firms that produce in that period, $P_{t} \tilde{d}_{t} N_{D, t}$. During period $t$, the representative home household buys $x_{t+1}$ shares in a mutual fund of $N_{H, t} \equiv N_{D, t}+N_{E, t}$ home firms (those already operating at time $t$ and the new entrants). Only $N_{D, t+1}=(1-\delta) N_{H, t}$ firms will produce and pay dividends at time $t+1$. Since the household does not know which firms will be hit by the exogenous exit shock $\delta$ at the very end of period $t$, it finances the continuing operation of all preexisting home firms and all new entrants during period $t$. The date $t$ price (in units of home currency) of a claim to the future profit stream of the mutual fund of $N_{H, t}$ firms is equal to the average nominal price of claims to future profits of home firms, $P_{t} \tilde{v}_{t}$.

The household enters period $t$ with bond holdings $B_{t}$ in units of consumption and mutual fund share holdings $x_{t}$. It receives gross interest income on bond holdings, dividend income on mutual fund share holdings and the value of selling its initial share position, and labor income. The household allocates these resources between purchases of bonds and shares to be carried into next period and consumption. The period budget constraint (in units of consumption) is

$$
B_{t+1}+\tilde{v}_{t} N_{H, t} x_{t+1}+C_{t}=\left(1+r_{t}\right) B_{t}+\left(\tilde{d}_{t}+\tilde{v}_{t}\right) N_{D, t} x_{t}+w_{t} L,
$$

where $r_{t}$ is the consumption-based interest rate on holdings of bonds between $t-1$ and $t$ (known with certainty as of $t-1$ ). The home household maximizes its expected intertemporal utility subject to (3).

The Euler equations for bond and share holdings are

$$
\begin{aligned}
\left(C_{t}\right)^{-\gamma} & =\beta\left(1+r_{t+1}\right) E_{t}\left[\left(C_{t+1}\right)^{-\gamma}\right], \\
\tilde{v}_{t} & =\beta(1-\delta) E_{t}\left[\left(\frac{C_{t+1}}{C_{t}}\right)^{-\gamma}\left(\tilde{v}_{t+1}+\tilde{d}_{t+1}\right)\right] .
\end{aligned}
$$


As expected, forward iteration of the equation for share holdings and absence of speculative bubbles yield the asset price solution in equation (2). ${ }^{17}$

\section{III.G. Aggregate Accounting and Balanced Trade}

Aggregating the budget constraint (3) across (symmetric) home households and imposing the equilibrium conditions under financial autarky $\left(B_{t+1}=B_{t}=0\right.$ and $\left.x_{t+1}=x_{t}=1\right)$ yields the aggregate accounting equation $C_{t}=w_{t} L+N_{D, t} \tilde{d}_{t}-N_{E, t} \tilde{v}_{t}$. A similar equation holds abroad. Consumption in each period must equal labor income plus investment income net of the cost of investing in new firms. Since this cost $N_{E, t} \tilde{v}_{t}$ is the value of home investment in new firms, aggregate accounting also states the familiar equality of spending (consumption plus investment) and income (labor plus dividend) that must hold under financial autarky. To close the model, observe that financial autarky implies balanced trade: the value of home exports must equal the value of foreign exports. Hence, $Q_{t} N_{X, t}\left(\tilde{\rho}_{X, t}\right){ }^{1-\theta} C_{t}^{*}=N_{X, t}^{*}\left(\tilde{\rho}_{X, t}^{*}\right){ }^{1-\theta} C_{t}$.

\section{III.H. Summary}

Table I summarizes the main equilibrium conditions of the model. The equations in the table constitute a system of nineteen equations in nineteen endogenous variables: $w_{t}, w_{t}^{*}, \tilde{d}_{t}, \tilde{d}_{t}^{*}, N_{E, t}$, $N_{E, t}^{*}, \tilde{z}_{X, t}, \tilde{z}_{X, t}^{*}, N_{D, t}, N_{D, t}^{*}, N_{X, t}, N_{X, t}^{*}, r_{t}, r_{t}^{*}, \tilde{v}_{t}, \tilde{v}_{t}^{*}, C_{t}, C_{t}^{*}, Q_{t}$. Of these endogenous variables, four are predetermined as of time $t$ : the total numbers of firms at home and abroad, $N_{D, t}$ and $N_{D, t}^{*}$, and the risk-free interest rates, $r_{t}$ and $r_{t}^{*}$. Additionally, the model features eight exogenous variables: the aggregate productivities $Z_{t}$ and $Z_{t}^{*}$, and the policy variables $f_{E, t}, f_{E, t}^{*}, f_{X, t}, f_{X, t}^{*}, \tau_{t}, \tau_{t}^{*}$. We interpret changes in $f_{E, t}$ and $f_{E, t}^{*}$ as changes in market regulation facing a country's firms in the respective domestic markets and changes in $f_{X, t}, f_{X, t}^{*}, \tau_{t}$, and $\tau_{t}^{*}$ as changes in trade policy. Since $f_{X, t}$ and $\tau_{t}$ are trade costs facing home firms, they are best interpreted as the foreign government's trade policy instruments.

17. We omit the transversality conditions for bonds and shares that must be satisfied to ensure optimality. The foreign household maximizes its utility function subject to a similar budget constraint, resulting in analogous Euler equations and transversality conditions. 
TABLE I

Model Summary-Financial Autarky

Price indexes

Profits

Free entry

Zero-profit export cutoffs

Share of exporting firms

Number of firms

Euler equation (bonds)

Euler equation (shares)

Aggregate accounting

Balanced trade

$$
\begin{aligned}
& N_{D, t}\left(\tilde{\rho}_{D, t}\right)^{1-\theta}+N_{X, t}^{*}\left(\tilde{\rho}_{X, t}^{*}\right)^{1-\theta}=1 \\
& N_{D, t}^{*}\left(\tilde{\rho}_{D, t}^{*}\right)^{1-\theta}+N_{X, t}\left(\tilde{\rho}_{X, t}\right)^{1-\theta}=1 \\
& \tilde{d}_{t}=\tilde{d}_{D, t}+\frac{N_{X, t}}{N_{D, t}} \tilde{d}_{X, t}
\end{aligned}
$$$$
\tilde{d}_{t}^{*}=\tilde{d}_{D, t}^{*}+\frac{N_{X, t}^{*}}{N_{D, t}^{*}} \tilde{d}_{X, t}^{*}
$$$$
\tilde{v}_{t}=w_{t} \frac{f_{E, t}}{Z_{t}}
$$

$$
\tilde{v}_{t}^{*}=w_{t}^{*} \frac{f_{E, t}^{*}}{Z_{t}^{*}}
$$$$
\tilde{d}_{X, t}=w_{t} \frac{f_{X, t}}{Z_{t}} \frac{\theta-1}{k-(\theta-1)}
$$$$
\tilde{d}_{X, t}^{*}=w_{t}^{*} \frac{f_{X, t}^{*}}{Z_{t}^{*}} \frac{\theta-1}{k-(\theta-1)}
$$$$
\frac{N_{X, t}}{N_{D, t}}=\left(z_{\min }\right)^{k}\left(\tilde{z}_{X, t}\right)^{-k}\left[\frac{k}{k-(\theta-1)}\right]^{k /(\theta-1)}
$$$$
\frac{N_{X, t}^{*}}{N_{D, t}^{*}}=\left(z_{\min }\right)^{k}\left(\tilde{z}_{X, t}^{*}\right)^{-k}\left[\frac{k}{k-(\theta-1)}\right]^{k /(\theta-1)}
$$$$
N_{D, t}=(1-\delta)\left(N_{D, t-1}+N_{E, t-1}\right)
$$$$
N_{D, t}^{*}=(1-\delta)\left(N_{D, t-1}^{*}+N_{E, t-1}^{*}\right)
$$$$
\left(C_{t}\right)^{-\gamma}=\beta\left(1+r_{t+1}\right) E_{t}\left[\left(C_{t+1}\right)^{-\gamma}\right]
$$$$
\left(C_{t}^{*}\right)^{-\gamma}=\beta\left(1+r_{t+1}^{*}\right) E_{t}\left[\left(C_{t+1}^{*}\right)^{-\gamma}\right]
$$$$
\tilde{v}_{t}=\beta(1-\delta) E_{t}\left[\left(\frac{C_{t+1}}{C_{t}}\right)^{-\gamma}\left(\tilde{v}_{t+1}+\tilde{d}_{t+1}\right)\right]
$$$$
\tilde{v}_{t}^{*}=\beta(1-\delta) E_{t}\left[\left(\frac{C_{t+1}^{*}}{C_{t}^{*}}\right)^{-\gamma}\left(\tilde{v}_{t+1}^{*}+\tilde{d}_{t+1}^{*}\right)\right]
$$$$
C_{t}=w_{t} L+N_{D, t} \tilde{d}_{t}-N_{E, t} \tilde{v}_{t}
$$$$
C_{t}^{*}=w_{t}^{*} L^{*}+N_{D, t}^{*} \tilde{d}_{t}^{*}-N_{E, t}^{*} \tilde{v}_{t}^{*}
$$

$$
Q_{t} N_{X, t}\left(\tilde{\rho}_{X, t}\right){ }^{1-\theta} C_{t}^{*}=N_{X, t}^{*}\left(\tilde{\rho}_{X, t}^{*}\right)^{1-\theta} C_{t}
$$

In the equations above, it must be understood that the average real prices and profits/dividends are functions of the average productivity levels (as previously defined): $\tilde{\rho}_{D, t} \equiv \rho_{D, t}\left(\tilde{z}_{D}\right), \tilde{\rho}_{X, t} \equiv \rho_{X, t}\left(\tilde{z}_{X, t}\right), \tilde{d}_{D, t} \equiv$ $d_{D, t}\left(\tilde{z}_{D}\right), \tilde{d}_{X, t} \equiv d_{X, t}\left(\tilde{z}_{X, t}\right)$. The same applies for the average foreign real prices and profits/dividends. (2) The zero-profit export cutoff conditions hold only when $f_{X, t}$ and $f_{X, t}^{*}$ are strictly positive. If all firms export (i.e., if $f_{X, t}=f_{X, t}^{*}=0$ ), then these conditions must be replaced with $\tilde{z}_{X, t}=\tilde{z}_{X, t}^{*}=\tilde{z}_{D}$. The same is true in the bond trading case.

\section{The Real Exchange Rate and the Harrod-Balassa-Samuelson EfFeCT}

Up to now, we have used a definition of the real exchange rate, $Q_{t} \equiv \varepsilon_{t} P_{t}^{*} / P_{t}$, computed using welfare-based price indexes $\left(P_{t}\right.$ and $\left.P_{t}^{*}\right)$. Under C.E.S. product differentiation, it is well- 
known that these price indexes can be decomposed into components reflecting average prices and product variety: $P_{t}=$ $N_{t}^{1 /(1-\theta)} \tilde{P}_{t}$ and $P_{t}^{*}=\left(N_{t}^{*}\right)^{1 /(1-\theta)} \tilde{P}_{t}^{*}$, where $N_{t} \equiv N_{D, t}+N_{X, t}^{*}$ $\left(N_{t}^{*} \equiv N_{D, t}^{*}+N_{X, t}\right)$ reflects product variety at home (foreign) and $\tilde{P}_{t}\left(\tilde{P}_{t}^{*}\right)$ is an average nominal price for all varieties sold in home (foreign). ${ }^{18}$ These average prices $\left(\tilde{P}_{t}, \tilde{P}_{t}^{*}\right)$ correspond much more closely to empirical measures such as the CPI then the welfarebased indexes. ${ }^{19}$ Thus, we define $\widetilde{Q}_{t} \equiv \varepsilon_{t} \tilde{P}_{t}^{*} / \tilde{P}_{t}$ as the theoretical counterpart to the empirical real exchange rate-since the latter relates CPI levels best represented by $\widetilde{P}_{t}$ and $\tilde{P}_{t}^{*}$. This real exchange rate deviates from the previously defined welfare-based measure $Q_{t}$ due to relative changes in product variety: $Q_{t}=$ $\left(N_{t} / N_{t}^{*}\right)^{1 /(\theta-1)} \tilde{Q}_{t}$. The differences between these two exchange rates can best be described using an example: $\tilde{Q}_{t}<1$ implies that average prices (expressed in a common currency) are higher in the home market. On the other hand, $Q_{t}$ measures differences in a consumer's welfare derived from spending a given nominal amount in each market (where the amount is converted at the nominal exchange rates). It is then possible for $Q_{t}>1$ even if $\tilde{Q}_{t}<1$, which implies that the consumer derives higher utility from spending the same amount in the home market with higher prices. This would be the case so long as product variety in the home market $N_{t}$ is sufficiently above that in the foreign market $N_{t}^{*}$. Our simulations will highlight such divergences between the real exchange rate (comparing CPI levels) and the welfare-based measure-driven by the crucial contribution of product variety differentials across countries. ${ }^{20}$

As we highlighted in the introduction, we will analyze our model's predictions for deviations (both permanent and transitory) from PPP in response to aggregate shocks. These will be given by the impulse responses for $\tilde{Q}_{t}$. In order to understand

18. $\tilde{P}_{t}$ is a weighted average of $\tilde{p}_{D, t}$ and $\tilde{p}_{X, t}^{*}$, the average prices of domestic goods and imports paid by home consumers, where the weights are proportional to the relative consumption levels of both types of goods. Similarly, $\tilde{P}_{t}^{*}$ is a weighted average of $\tilde{p}_{D, t}^{*}$ and $\tilde{p}_{X, t}$.

19. Feenstra [1994] develops a similar decomposition (also allowing for preference asymmetries between varieties) to address empirically the impact of increasing product variety. Broda and Weinstein [2003] also use this decomposition for U. S. import prices and find that increases in imported product variety significantly contribute to unmeasured welfare benefits for U. S. consumers.

20 . We do not address the growth effects of changes in product variety. Bils and Klenow [2001] document that these effects are empirically relevant for the United States. 
how and why $\tilde{Q}_{t}$ may deviate from 1 , we use the price index equations to write it in the following way:

$$
\begin{aligned}
\tilde{Q}_{t}^{1-\theta}=\left[\frac{N_{D, t}^{*}}{N_{t}^{*}}\left(T O L_{t}\right)^{1-\theta}+\frac{N_{X, t}}{N_{t}^{*}}\left(\tau_{t} \frac{\tilde{z}_{D}}{\tilde{z}_{X, t}}\right)^{1-\theta}\right] / \\
\\
{\left[\frac{N_{D, t}}{N_{t}}+\frac{N_{X, t}^{*}}{N_{t}}\left(T O L_{t} \tau_{t}^{*} \tilde{z}_{\tilde{z}_{X, t}^{*}}^{\tilde{z}_{D}^{*}}\right)^{1-\theta}\right], }
\end{aligned}
$$

defining $T O L_{t} \equiv \varepsilon_{t}\left(W_{t}^{*} / Z_{t}^{*}\right) /\left(W_{t} / Z_{t}\right)$ as the "terms of labor."1 $T O L_{t}$ measures the relative cost of effective units of labor across countries. A decrease in $T O L_{t}$ indicates an appreciation of home effective labor relative to foreign: if $T O L_{t}<1$, a firm with given productivity $z$ could produce any amount of output at lower cost in the foreign country than in home. Note that, absent trade costs, PPP would always hold: $\tilde{Q}_{t}=1, \forall t .^{22}$

Dropping time subscripts to denote a variable's level in steady state, we assume that $f_{E}=f_{E}^{*}, f_{X}=f_{X}^{*}, \tau=\tau^{*}, L=$ $L^{*}=1, Z=Z^{*}=1$. In a technical appendix available on request, we demonstrate existence and uniqueness of a symmetric steady state under these assumptions where $\tilde{Q}=Q=T O L=$ 1. Using sans-serif fonts to denote percentage deviations from this steady state, log-linearizing (4) yields

$$
\begin{aligned}
\tilde{\mathrm{Q}}_{t}=\left(2 s_{D}-1\right) \mathrm{TOL}_{t}-\left(1-s_{D}\right)\left[\left(\tilde{\mathrm{z}}_{X, t}-\tilde{\mathrm{z}}_{X, t}^{*}\right)-\left(\mathrm{t}_{t}-\mathrm{t}_{t}^{\star}\right)\right] \\
\quad+\frac{1}{\theta-1}\left(\frac{N_{D}}{N_{D}+N_{X}}-s_{D}\right)\left[\left(\mathrm{N}_{D, t}^{\star}-\mathrm{N}_{X, t}\right)-\left(\mathrm{N}_{D, t}-\mathrm{N}_{X, t}^{\star}\right)\right],
\end{aligned}
$$

where $s_{D}$ is the steady-state share of spending on domestic goods $\left(s_{D, t} \equiv N_{D, t}\left(\tilde{\rho}_{D, t}\right)^{1-\theta}\right)$ and $\mathrm{t}_{t}\left(\mathrm{t}_{t}^{*}\right)$ denotes the percentage deviation of $\tau_{t}\left(\tau_{t}^{*}\right)$ from the steady state. Equation (5) highlights three important channels for real exchange rate changes: 1 ) given the

21. This is related to the double factorial terms of trade. The two concepts are distinct because our measure adjusts for the productivity of all labor, not just the productivity in the export and import sectors (which are endogenous in our model).

22. When $f_{X, t}=f_{X, t}^{*}=0$, all firms export: $N_{X, t}=N_{D, t}$, and $N_{X, t}^{*}=N_{D, t}^{*}$. If, in addition, $\tau_{t}=\tau_{t}^{*}=1$, it is immediate from (4) that $\widetilde{Q}_{t}=1$ (and hence $Q_{t} \stackrel{D, t}{=} 1$ ). Note that this property does not imply that there can be no movements in the terms of trade. Absent trade costs, balanced trade under financial autarky would imply that $\tilde{T}_{t}^{\theta-1}\left(C_{t} / C_{t}^{*}\right)=N_{D, t} / N_{D, t}^{*}$, where $\tilde{T}_{t} \equiv \varepsilon_{t} \tilde{p}_{X, t} / \tilde{p}_{X, t}^{*}$ denotes the average terms of trade. With constant numbers of firms at home and abroad, as in more standard macroeconomic models, $\tilde{T}_{t}^{\theta-1}\left(C_{t} / C_{t}^{*}\right)$ is constant. Hence, shocks that cause the consumption differential $C_{t}^{t} / C_{t}^{*}$ to increase (such as an increase in home productivity) always result in a deterioration of the terms of trade-leaving $\widetilde{Q}_{t}=$ $Q_{t}=1, \forall t$. In our model, firm entry dampens this deterioration of the terms of trade. (We discuss terms of trade dynamics in our model in Section V.) 
existence of a nontraded sector under costly trade (which implies that $\left.s_{D}>1 / 2\right)$, changes in the relative cost of labor $\left(T O L_{t}\right)$ lead to relative price differences for nontraded goods across countries.

2) Changes in relative import prices. These can happen exogenously when tariffs change, but more importantly, these relative prices endogenously change with relative changes in the export productivity cutoffs (driven by entry and exit decisions for the export market). ${ }^{23} 3$ ) An expenditure switching channel. Plausible parameter values imply that $N_{D} /\left(N_{D}+N_{X}\right)>s_{D}$ in the symmetric steady state. This will be the case whenever average prices $\tilde{p}_{D}=\tilde{p}_{D}^{*}$, which include the high prices of the least productive firms that do not export, are higher than average import prices $\tilde{p}_{X}=\tilde{p}_{X}^{*}{ }^{24}$ Changes in the relative availability of domestic and imported varieties $\left(N_{D, t} / N_{X, t}^{*}\right.$ and $\left.N_{D, t}^{*} / N_{X, t}\right)$ then induce expenditure switching effects for the real exchange rate.

The endogenous HBS effect mentioned in the introduction occurs through all three of these channels, reinforcing the real exchange rate appreciation in response to increases in aggregate productivity or deregulation. Before analyzing the full response path of $\tilde{Q}_{t}$ and other key endogenous variables to these shocks, we first describe the long-run effects of permanent changes in productivity and deregulation. These effects also highlight steadystate differences for an asymmetric version of our model.

Consider a permanent increase in home productivity $Z_{t}$ or a permanent decrease in home entry $\operatorname{costs} f_{E, t}$ (which we interpret as permanent deregulation as in Blanchard and Giavazzi [2003]). Relative to the old steady state, the home market becomes a more attractive location for prospective entrants. (When productivity increases, the home market becomes more attractive due to its increased size. The standard "home market effect" of new trade theory models with trade costs then implies that home attracts a bigger share of firms than its relative size in the world econ-

23. Since the average export productivity level $\tilde{z}_{X_{1} t}$ is proportional to the cutoff $z_{X, t}$, their percentage changes from steady-state levels are identical. The same holds for $\tilde{z}_{X, t}^{*}$ and $z_{X, t}^{*}$. Statistical agencies typically do not adjust price indexes to reflect differences in the price levels of new goods. Thus, the contribution of the newly imported goods to the aggregate relative price $\tilde{Q}_{t}$ would go unmeasured (except when price hedonics are used). However, this particular channel is not crucial in generating changes in $\hat{Q}_{t}$.

24 . This condition is equivalent to $\tilde{z}_{X}>\tau \tilde{z}_{D}$ : the productivity advantage of exporters is larger than the iceberg export cost. 
omy. ${ }^{25}$ ) Absent any change in the relative cost of effective labor $\left(T O L_{t}\right)$, all new firms would only enter the home market (there would be no new entrants into the foreign market). Thus, in the new long-run equilibrium, home effective labor units must appreciate $\left(T O L_{t}\right.$ decreases) in order to keep foreign labor employed. ${ }^{26}$ This causes the relative price of nontraded goods at home to increase relative to foreign (the first channel for real exchange rate appreciation). The higher relative labor costs at home reduce the export profitability of home firms, and conversely increase that of foreign firms. Hence, the export cutoff for home firms, $z_{X, t}$, rises (only relatively more productive home firms export) and the cutoff for foreign firms, $z_{X, t}^{*}$, drops (relatively less productive foreign firms can now profitably export). This induces an increase in the average price of home imports relative to the average price of foreign imports (the second channel for appreciation). ${ }^{27}$ Last, the increase in the number of domestic varieties relative to foreign ones available to home consumers (generated by entry into the more attractive market) induces those consumers to switch their expenditures toward home-produced goods (whose prices, on average, are higher than imported goods). This is the third channel for real exchange rate appreciation. ${ }^{28}$

All three channels generating the endogenous HBS effect in our model critically depend on the incorporation of endogenous entry (and the associated endogenous location of new firms across countries). It is this key feature that generates the appreciation of home labor in response to the accelerated entry of firms in the relatively more favorable business environment at home. Without this feature, home effective labor would depreciate in response to a favorable aggregate productivity shock at home (when the number of firms is fixed, the increased demand by home consumers for foreign varieties-whose productivity remains unchanged-leads to an excess demand for foreign labor). We highlight this property

25. Without trade costs, entry in the home economy relative to foreign in the new long-run equilibrium would be directly proportional to the change in relative market size.

26. Absent entry into the foreign country, the number of foreign producing firms would steadily decrease with the "death" shock.

27. After an increase in home productivity, the total number of home exporters $N_{X, t}$ is higher in the new long-run equilibrium (compared with the initial steady state). However, relatively less productive home exporters have dropped out of the export market.

28 . Foreign consumers also switch their expenditures between domestic and imported varieties. The direction depends on the type of shock (productivity increase versus deregulation) but the effect is always dominated by the expenditure switching for home consumers. 
in our dynamic simulations. Although our model also captures an additional channel for real exchange rate appreciation via endogenous nontradedness, the appreciation of home effective labor along with an exogenous nontraded sector is enough to generate real exchange rate appreciation and the HBS effect.

Our model also provides a new explanation for the pervasive evidence that real exchange rate appreciations are associated with increases in the cross-country relative price of tradable goods (usually referred to as traded goods). This does not preclude the contribution of the traditional HBS channel. If there are exogenously nontradable sectors whose productivity lags behind the tradable sector, the traditional mechanism operates, amplifying the appreciation.

We conclude this section with two important observations. First, when product variety is endogenous, an appreciation in average relative prices ( $\tilde{Q}_{t}$ decreases) need not lead to an appreciation of the welfare-based real exchange rate $Q_{t}$ : the simulations described in the next section show that the relative increase in product variety at home overwhelmingly dominates the increase in average prices, leading to a depreciation of this welfarebased index. Second, equation (4) and its log-linear counterpart (5) do not depend on the assumption of financial autarky. In particular, these equations still hold when we introduce international bond trading-and would also hold under other assumptions on asset markets. The international-bond-trading scenario will thus feature the same three channels for real exchange rate dynamics.

\section{International Trade and Macroeconomic Dynamics}

We now analyze the full response path of the real exchange rate and other key variables in response to permanent and transitory shocks to productivity, and permanent deregulation. ${ }^{29}$ To do so, we log-linearize the system of equilibrium conditions in Table I around the unique symmetric steady state under assumptions of log-normality and homoskedasticity of exogenous stochastic shocks. We calibrate parameters, compute the implied steady-state levels of endogenous variables, and numerically

29. We discuss the consequences of worldwide trade liberalization in the Appendix. 
solve for the dynamic responses to exogenous shocks using the method of undetermined coefficients.

\section{V.A. Calibration}

We calibrate parameters as follows. We interpret periods as quarters and set $\beta=.99$ and $\gamma=2$-both standard choices for quarterly business cycle models. We set the size of the exogenous firm exit shock $\delta=.025$ to match the U. S. empirical level of 10 percent job destruction per year. ${ }^{30}$ We use the value of $\theta$ from Bernard, Eaton, Jensen, and Kortum [BEJK 2003] and set $\theta=$ 3.8 , which was calibrated to fit U. S. plant and macro trade data. BEJK also report that the standard deviation of log U. S. plant sales is 1.67. In our theoretical model, this standard deviation is equal to $1 /(k-\theta+1)$. The choice of $\theta=3.8$ then implies that $k=$ 3.4 (this satisfies the requirement $k>\theta-1$ ). We postulate that $\tau=1.3$, roughly in line with Obstfeld and Rogoff [2001], and set the steady-state fixed export $\operatorname{cost} f_{X}$ such that the proportion of exporting plants matches the number reported in BEJK (21 percent). This leads to a fixed export $\operatorname{cost} f_{X}$ equal to 23.5 percent of the per-period, amortized flow value of the entry cost, $[1-\beta(1-$ $\delta)] /[\beta(1-\delta)] f_{E} \cdot{ }^{31}$ Changing the entry cost $f_{E}$ while maintaining the same ratio $f_{X} / f_{E}$ does not affect any of the impulse responses. ${ }^{32}$ We therefore set $f_{E}$ to 1 without loss of generality. For similar reasons, we normalize $z_{\min }$ to 1 . Our calibration implies that exporters are on average 58.2 percent more productive than nonexporters. The steady-state share of expenditure on domestic goods is .733, and the share of expenditure on nontraded domestic goods is .176. The relative size differential of exporters relative to nonexporters in the domestic market is 3.61.

It may be argued that the value of $\theta$ results in a steady-state markup that is too high relative to the evidence. A standard choice in the macro literature is $\theta=6$ to deliver a 20 percent

30. Empirically, job destruction is induced by both firm exit and contraction. In our model, the "death" shock $\delta$ takes place at the product level. In a multiproduct firm, the disappearance of a product generates job destruction without firm exit. Since we abstract from the explicit modeling of multiproduct firms, we include this portion of job destruction in $\delta$.

31 . We tried using different values of $\tau(1.1,1.2,1.25)$ and recalculated $f_{X}$ relative to $f_{E}$ to match the 21 percent of exporting plants. The impulse responses were very similar in all cases.

32 . The total number of firms in steady state is inversely proportional to $f_{E}$-and the size and value of all firms are similarly proportional to $f_{E}$. Basically, changing $f_{E}$ for given ratio $f_{X} / f_{E}$ amounts to changing the unit of measure for output and number of firms. 
markup of price over marginal cost [Rotemberg and Woodford 1992]. However, it is important to observe that, in models without any fixed cost, $\theta /(\theta-1)$ is a measure of both markup over marginal cost and average cost. In our model with entry costs, free entry ensures that, on average, firms earn zero profits net of the entry cost. This means that, on average, firms price at average cost (inclusive of the entry cost). The markup over average cost increases with firm productivity. The firm with productivity $z_{\text {min }}$ always prices below average cost: the net present value of its profits does not cover the entry cost. Thus, although $\theta=3.8$ implies a fairly high markup over marginal cost, our parameterization delivers reasonable markups over average costs.

\section{V.B. Impulse Responses}

Figures I and II show the responses (percent deviations from steady state) to a permanent 1 percent increase in home productivity and a permanent 1 percent decrease in home entry costs. The number of years after the shock is on the horizontal axis. Consider first the long-run effects in the new steady state. As was previously described, the home market becomes a relatively more attractive business environment, drawing a permanently higher number of entrants, which translates into a permanently higher number of producers. This induces the new steady state for $T O L_{t}$ below 1. This appreciation of home labor costs (which raises the relative costs of home exporters and decreases those of foreign exporters) leads to a long-run increase in $z_{X, t}$ and a decrease in $z_{X, t}^{*}$. These effects combine to induce a long-run appreciation of the real exchange rate $\tilde{Q}_{t}$. However, our simulations suggest that the increase in product variety for home consumers dominates this average price appreciation, leading to a depreciation of the welfare-based index $Q_{t}$. Thus, consumers in both countries would rather spend a given nominal expenditure in the home market, even though average prices there are relatively higher. ${ }^{33}$

We now describe the transitional changes in response to the permanent home productivity increase (summarized by the impulse responses in Figure I). Absent sunk entry costs, and the associated time-to-build lag before production starts, the number of producing firms $N_{D, t}$ would immediately adjust to its new

33. We have experimented with numerous different parameter choices, and always obtained this long-run dichotomy between the real exchange rate $\tilde{Q}_{t}$ and its welfare-based counterpart $Q_{t}$. 

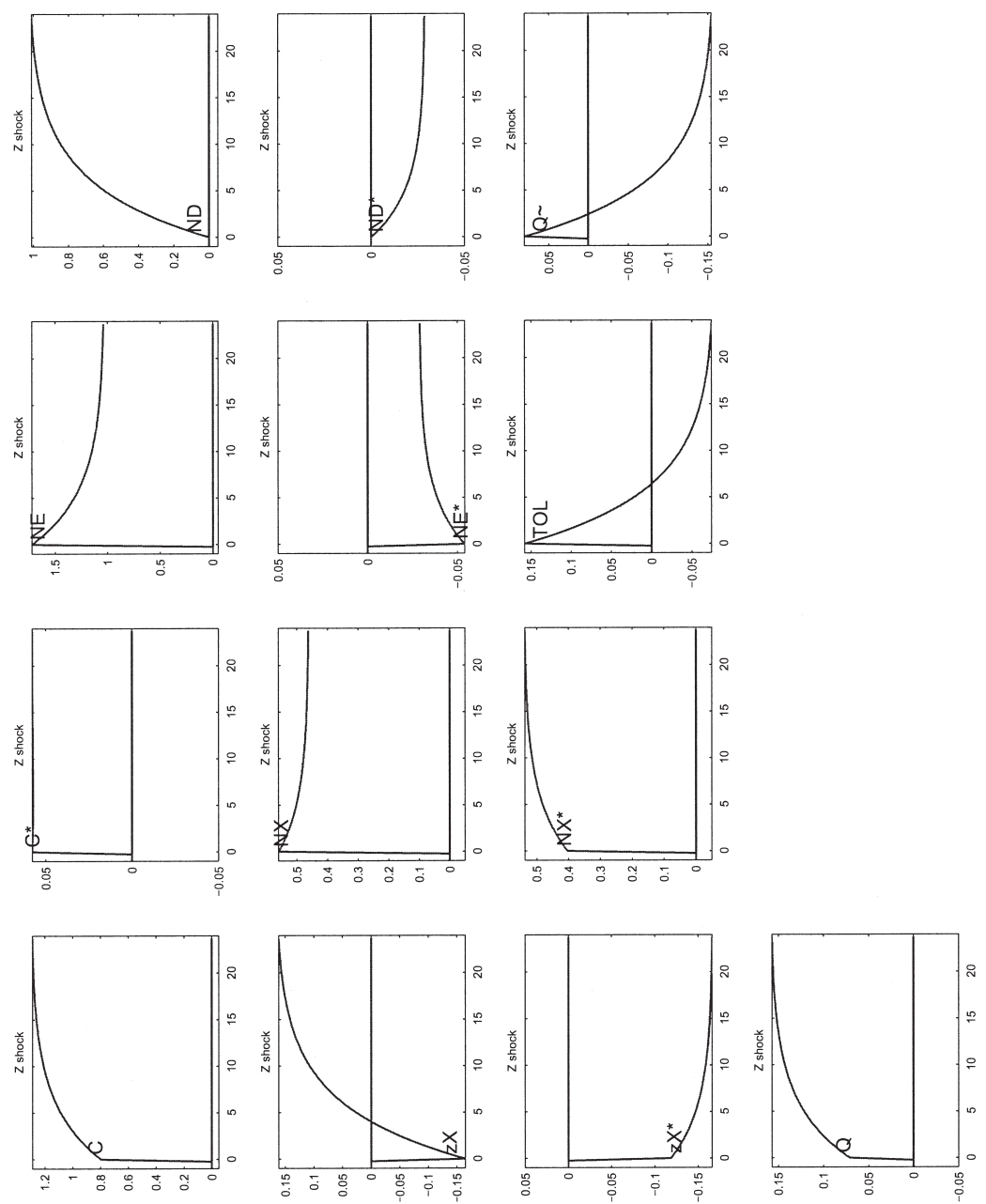

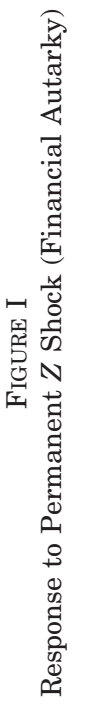



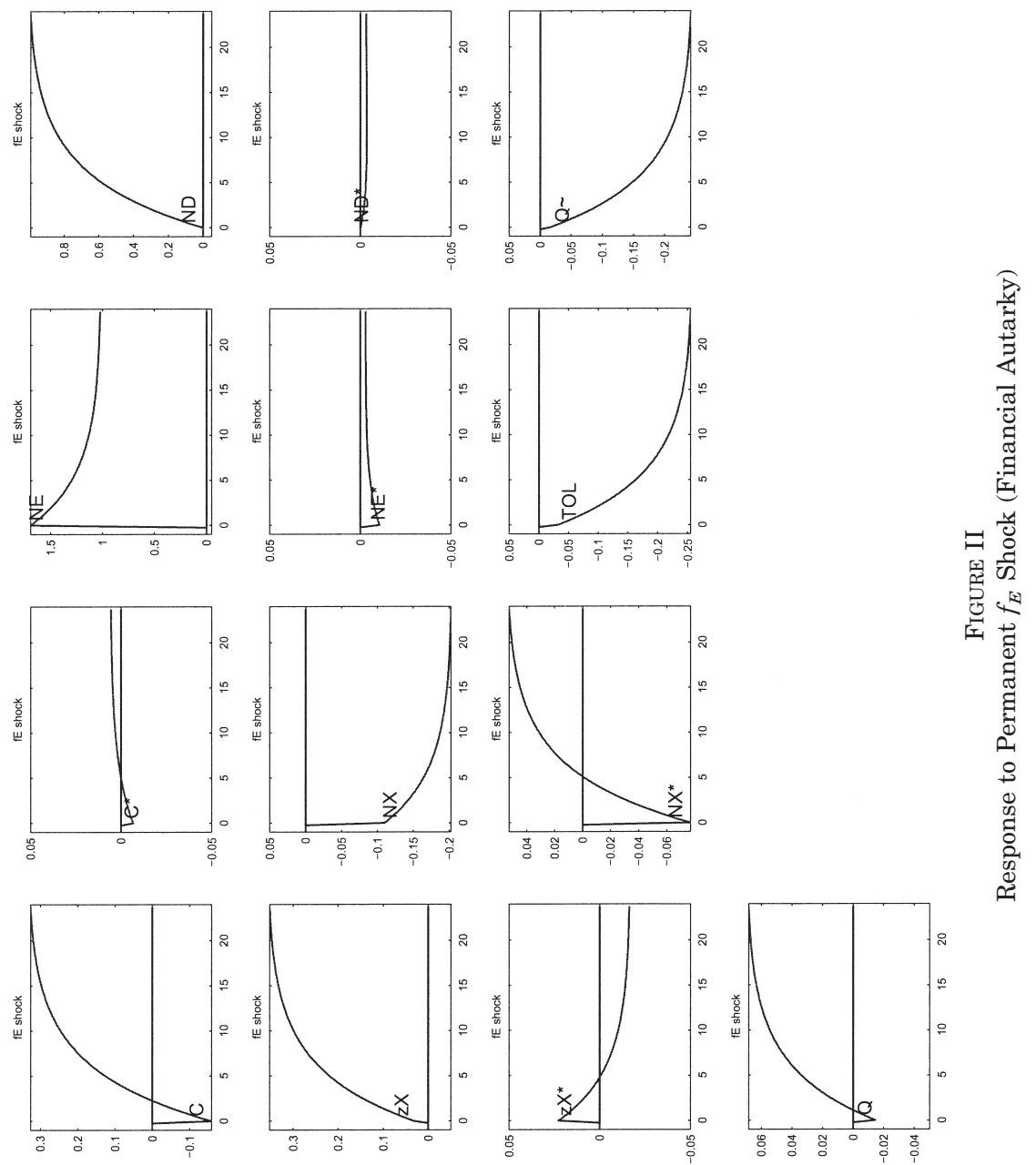
steady-state level. Sunk costs and time-to-build transform $N_{D, t}$ into a state variable that behaves very much like a capital stock: the number of entrants $N_{E, t}$ represents the home consumers' investment, which translates into increases in the stock $N_{D, t}$ over time. The immediate impact of the productivity increase on $T O L_{t}$ (which increases) is typical of open economy, macroeconomic models without entry (with or without capital): there is an immediate increase in demand for all existing goods (domestic and foreign) sold in the home market. The increase in home labor productivity then translates into an excess supply of home effective labor units relative to foreign-whose productivity is unchanged. The resulting short-run depreciation of home labor then leads to a short-run decrease in the home export cutoff $z_{X, t}$ and a short-run depreciation of the real exchange rate $\tilde{Q}_{t}$. The foreign export cutoff falls nonetheless, as the short-run increase in the foreign exporters' relative cost is dominated by the increase in home demand (for all existing goods, including imports). The numbers of home and foreign exporters, $N_{X, t}$ and $N_{X, t}^{*}$, increase on impact as the export productivity cutoffs fall. From this point on, the number of home producers $N_{D, t}$ steadily increases; this steadily shifts the increase in home demand toward domestic varieties (and away from foreign varieties). The effect of endogenous entry is crucial, as the labor demand generated by a greater number of home firms translates into an appreciation of home labor units, reversing the initial change in $T O L_{t}, z_{X, t}$, and the real exchange rate $\tilde{Q}_{t}$. Entry of new domestic firms pushes $N_{X, t}$ upward, but the reversal in the dynamics of $z_{X, t}$ has the opposite effect. The net result is that $N_{X, t}$ settles at a higher level than in the initial steady state: the larger number of more productive home firms ensures that $N_{X, t}$ is higher even if relatively less productive exporters have dropped out. Yet, the long-run response of $N_{X, t}$ is smaller than the shortrun effect as the less productive exporters drop out during the transition.

The path of endogenous variables in Figure I highlights the importance of the microeconomic dynamics in our model relative to the standard setup with a constant number of firms: absent entry, $T O L_{t}$ would remain depreciated in the long run, as would $\tilde{Q}_{t} \cdot{ }^{34}$ Note that, even though prices are fully flexible, the real exchange rate appreciation takes a long time to unfold, reaching

34. When we allow for international trade in bonds, the accelerated entry of firms in the home market financed by borrowing causes $T O L_{t}$ to appreciate also 
less than half of its long-run appreciation within five years of the permanent productivity increase.

In our model, endogenous entry also crucially affects the evolution of the terms of trade. In models with a constant number of firms, the induced excess demand for foreign labor and depreciation in $T O L_{t}$ are also manifested in a strong deterioration of home's terms of trade. This prediction is hard to square with the empirical evidence that suggests a link between productivity gains and improvements in a country's terms of trade. ${ }^{35}$ Our model shows how the entry of new producers and varieties in the more productive economy may dampen or even reverse the deterioration in the terms of trade. In particular, for any given home and foreign exporters with productivity $z$ and $z^{*}$ (whose trade status does not change with the productivity shock), the relative price $T_{t} \equiv \varepsilon_{t} p_{X, t}(z) / p_{X, t}^{*}\left(z^{*}\right)=\left(z^{*} / z\right)\left(\tau_{t} / \tau_{t}^{*}\right) T O L_{t}^{-1}$ increases (due to the appreciation in $T O L_{t}$ ) - except initially. ${ }^{36}$

We now turn to the transitional changes in response to permanent deregulation (summarized by the impulse responses in Figure II). In contrast to the previous scenario, deregulation does not increase the available supply of effective labor units for production in the home market. Thus, there is no short-run excess supply of home effective labor units, and $T O L_{t}$ steadily appreciates over time with the increase in home labor demand generated by entry (the appreciation in $T O L_{t}$ is therefore amplified relative to the productivity scenario). There is thus no reversal in the paths of $T O L_{t}, z_{X, t}$, and $\tilde{Q}_{t}$. The response in the number of home exporters $N_{X, t}$ reflects the opposing effects of the increase in the total number of producers $N_{D, t}$ and the increase in the export productivity cutoff $z_{X, t}$. The immediate increase in the latter causes $N_{X, t}$ to fall on impact. Subsequently, since the increase in $z_{X, t}$ is amplified relative to the productivity scenario (due to the amplified appreciation in $T O L_{t}$ ), its effect dominates the effect of

in the short run. There is then no reversal in the paths of $T O L_{t}, z_{X, t}$, and $\tilde{Q}_{t}$. We describe this in further detail in the following section.

35. For instance, see Corsetti, Dedola, and Leduc [2004].

36. The initial deterioration of $T_{t}$ is much shorter-lived when the productivity increase is not permanent. The average terms of trade $\tilde{T}_{t} \equiv \varepsilon_{t} \tilde{p}_{X, t} / \tilde{p}_{X, t}^{*}=\left(\tilde{z}_{X, t}^{*}\right)$ $\left.\tilde{z}_{X, t}\right)\left(\tau_{t} / \tau_{t}^{*}\right) T O L_{t}^{-1}$ decreases in our exercise due to the dominating effect of the change in the composition of exports (driven by the changes in the cutoffs $z_{X, t}$ and $\left.z_{X, t}^{*}\right)$. Nevertheless, as previously mentioned, this deterioration is dampened relative to the case where the number of home producers is fixed. Gagnon [2003] finds strong empirical support for the positive effect of entry on the terms of trade, first analyzed by Krugman [1989]. 
higher $N_{D, t}$, leading to a further decrease in $N_{X, t}$. Another major difference in the current scenario is that home consumption decreases in the short run, in order to finance the entry of new firms (this requires a much greater reallocation of effective labor units away from production as the supply of these labor units is unaffected by deregulation). The initial decrease in home import demand leads to an initial increase in the foreign export productivity cutoff $z_{X, t}^{*}$ and an associated decrease in the number of foreign exporters. These changes are reversed as home consumption recovers. As was the case with the productivity increase, we note that the real exchange rate appreciation is slow to unfold. Again, less than half of the long-run appreciation occurs within five years of the permanent deregulation shock.

We further illustrate the endogenous persistence properties of our model by showing the impulse responses to a transitory increase in home productivity. These responses are illustrated in Figure III, where $Z_{t}=.9 Z_{t-1}, \forall \mathrm{t}>0$. As the responses clearly show, the shock has no permanent effect since all endogenous variables are stationary in response to stationary exogenous shocks. However, the responses also clearly highlight the substantial persistence of key endogenous variables-well beyond the exogenous .9 persistence of the productivity shock. Approximately 84 percent of the initial increase in productivity has been reabsorbed ten years after the shock. At that point in time, the real exchange rate $\tilde{Q}_{t}$ still needs to cover roughly half the distance between the peak appreciation (which happens approximately four years after the shock) and the steady state. ${ }^{37}$

A large literature has developed in the past few years striving to explain empirical real exchange rate movements with models that feature nominal rigidity and local currency pricing (see Chari, Kehoe, and McGrattan [2002] and references therein). The success has been, at best, mixed (especially for models with monopolistic competition that-like ours-are best interpreted as one-sector models and should thus explain persistence in sectoral relative prices). Plausible degrees of nominal rigidity and local currency pricing (supported by the assumption of market segmen-

37. Although persistence .9 is already low by $\mathrm{RBC}$ standards, this result is robust to lower persistence of the productivity shock. If $Z_{t}=.5 Z_{t-1}, \forall t>0,99$ percent of the shock has died out within two years, while $\tilde{Q}_{t}$ still needs to cover more than half the distance to the steady state after five years. $Q_{t}$ is roughly halfway to the steady state even five years after a zero-persistence shock. The result also does not depend on the presence of a steady-state iceberg cost $\tau=$ $\tau^{*} \neq 1$. A similarly persistent deviation from PPP happens if $\tau=\tau^{*}=1$. 

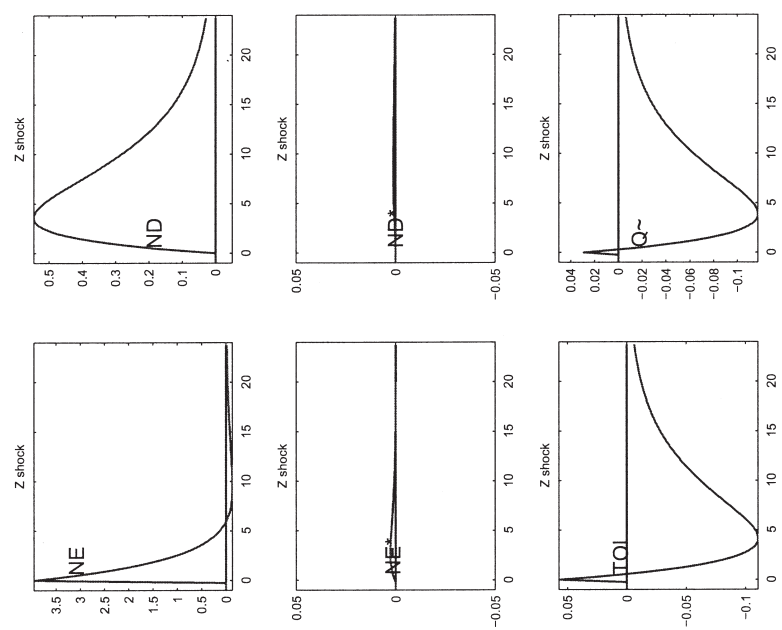

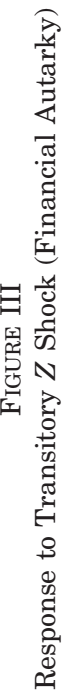
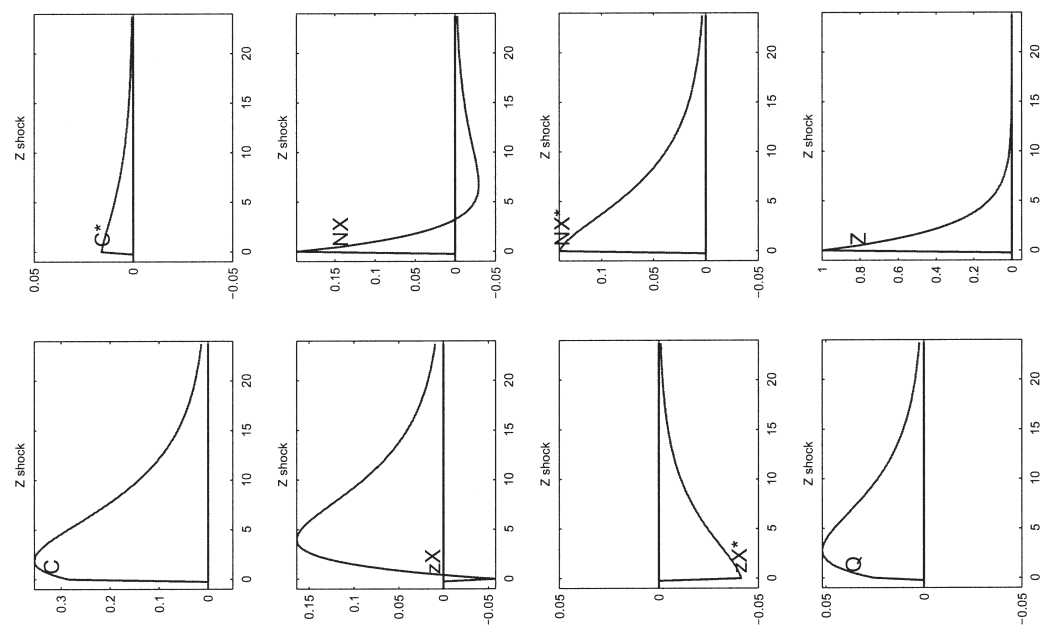
tation) succeed in generating volatile real exchange rates, but only special assumptions deliver persistence in line with the data. Benigno [2004] highlights inertia in endogenous interest rate setting by central banks and differences in nominal rigidity as sources of real exchange rate persistence. Burstein, Neves, and Rebelo [2003] and Corsetti and Dedola [forthcoming] incorporate a nontraded distribution sector, pointing to structural features beyond nominal rigidity that matter for real exchange rate dynamics. We propose a different mechanism that delivers substantial real exchange rate persistence in response to transitory shocks: firm entry and reallocation in and out of markets in a world of flexible prices.

\section{International Trade in BondS}

We now extend the model of Section III to allow for international trade in bonds. We study how international bond trading affects the results we have previously described and how our new microeconomic dynamics affect the current account. Since the extension to international borrowing and lending does not involve especially innovative features relative to the financial autarky setup, we herein limit ourselves to describing its main ingredients in words and present the relevant model equations in the Appendix.

We assume that agents can trade bonds domestically and internationally. Home bonds, issued by home households, are denominated in home currency. Foreign bonds, issued by foreign households, are denominated in foreign currency. We maintain the assumption that nominal returns are indexed to inflation in each country, so that bonds issued by each country provide a risk-free, real return in units of that country's consumption basket. International asset markets are incomplete, as only risk-free bonds are traded across countries. In the absence of any other change to our model, this would imply indeterminacy of steadystate net foreign assets and nonstationarity. The choice of initial conditions would then become a matter of convenience, and all shocks would have permanent consequences via wealth reallocation across countries (regardless of the nature of the disturbances). Such a setup would undermine the reliability of loglinear approximation and the validity of stochastic analysis. (Ghironi [2000] discusses the issue in detail.) To solve this problem, we assume that agents must pay fees to domestic financial inter- 
mediaries when adjusting their bond holdings. We assume that these fees are a quadratic function of the stock of bonds. This convenient specification is sufficient to uniquely pin down the steady state and deliver stationary model dynamics in response to temporary shocks. Realistic choices of parameter values imply that the cost of adjusting bond holdings has a very small impact on model dynamics, other than pinning down the steady state and ensuring mean reversion in the long run when shocks are transitory. ${ }^{38}$

We assume that financial intermediaries rebate the revenues from bond-adjustment fees to domestic households. In equilibrium, the markets for home and foreign bonds clear, and each country's net foreign assets entering period $t+1$ depend on interest income from asset holdings entering period $t$, labor income, net investment income, and consumption during period $t$. The change in asset holdings between $t$ and $t+1$ is the country's current account. Home and foreign current accounts add to zero when expressed in units of the same consumption basket. There are now three Euler equations in each country: the Euler equation for share holdings, which is unchanged, and Euler equations for holdings of domestic and foreign bonds. The fees for adjusting bond holdings imply that the Euler equations for bond holdings feature a term that depends on the stock of bonds-a key ingredient delivering determinacy of the steady state and model stationarity. Euler equations for bond holdings in each country imply a no-arbitrage condition between bonds. In the log-linear model, this no-arbitrage condition relates (in a standard fashion) the real interest rate differential across countries to expected depreciation of the consumption-based real exchange rate.

The balanced trade condition closed the model under financial autarky. Since trade is no longer balanced under international bond trading, we must explicitly impose labor market clearing conditions in both countries. ${ }^{39}$ These conditions state that the amount of labor used in production and to cover entry costs and fixed export costs in each country must equal labor supply in that country in each period. The costs of adjusting bond

38. Under financial autarky, introducing costs of adjusting bond holdings of the type we consider would have no effect on the system of equilibrium conditions in Table I, since holdings of bonds are always zero in equilibrium.

39. In the technical appendix we show that, under financial autarky, balanced trade implies labor market clearing in each country. 
holdings imply zero holdings (of both domestic and foreign bonds) in the unique symmetric steady state. Thus, the extended model with international bond trading features exactly the same steady state as the model under financial autarky. As before, we loglinearize the system and solve it using the method of undetermined coefficients. ${ }^{40}$ We set the scale parameter for the bond adjustment cost to .0025 - sufficient to generate stationarity in response to transitory shocks but small enough to avoid overstating the role of this friction in determining the dynamics of our model.

\section{VI.A. Impulse Responses}

We consider the same productivity and deregulation shocks as under financial autarky. Figure IV shows impulse responses to a permanent 1 percent increase in home productivity. The response of several key variables to the shock is qualitatively similar to that under financial autarky. The permanent nature of the shock implies that home households do not have an incentive to adjust their net foreign asset position to smooth the effect of a transitory fluctuation in income. The path of $C$ is therefore very similar to that in Figure I.

The home economy runs a current account deficit in response to the shock and accumulates net foreign debt. ${ }^{41}$ Home households borrow from abroad to finance higher initial investment (relative to autarky) in new home firms. This is apparent in the different responses of $N_{E, t}$ in the initial years after the shock (Figure IV relative to Figure I). The home household's incentive to front-load entry of more productive firms is mirrored by the foreign household's desire to invest savings in the more attractive economy. Although foreign households cannot hold shares in the mutual portfolio of home firms (since only bonds can be traded across countries), the return on bond holdings is tied to the return on holdings of shares in home firms by no-arbitrage between bonds and shares within the home economy. Therefore, foreign

40. Since steady-state holdings of bonds are zero, the percentage deviations of bond stocks from the steady state (used in the log-linearization) are normalized using the steady-state level of consumption (for instance, $\mathrm{B}_{t+1} \equiv d B_{t+1} / C$ ). Similar normalizations are applied for the current account and the trade balance.

41. In Figure IV, ca denotes the current account. The impulse response of the asset stock a cumulates holdings of domestic and foreign bonds. It shows the level of a at the end of each period. The response of the trade balance (omitted) is similar to that of the current account in all the examples we consider. 

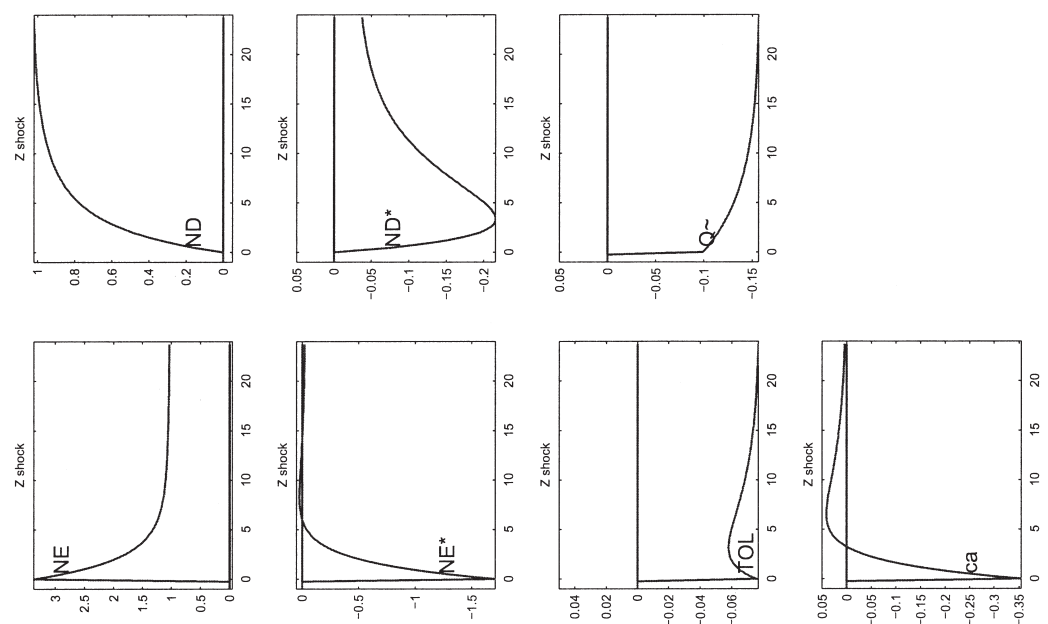

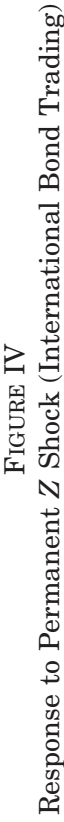
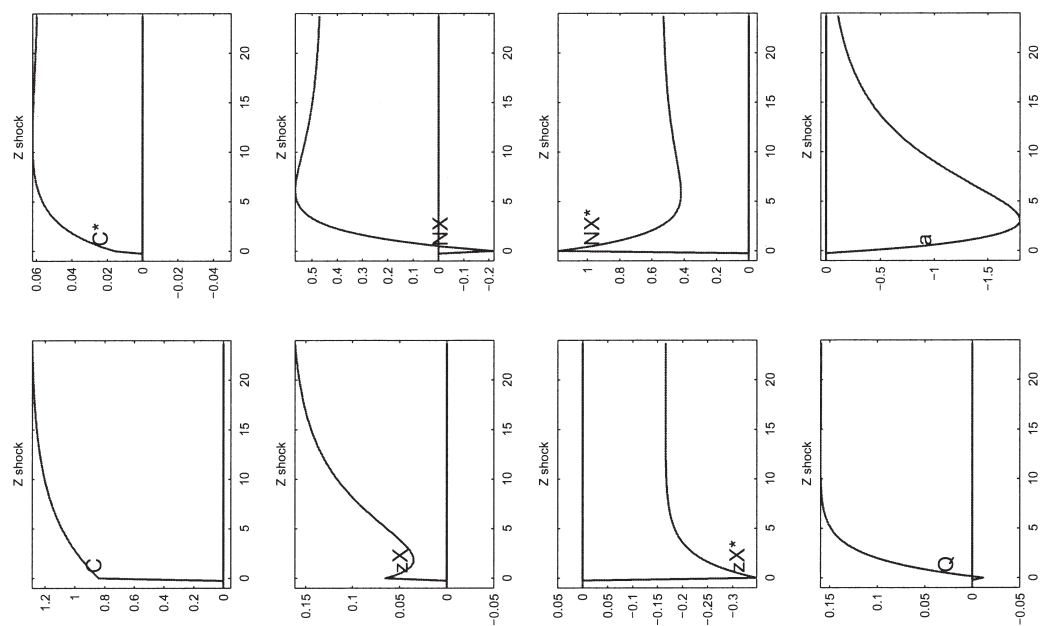
households share the benefits of higher home productivity via lending. ${ }^{42}$

As in the case of financial autarky, TOL must decrease in the long run (home effective labor must relatively appreciate); otherwise, all new entrants would choose to locate in the home economy. The accelerated entry of new home firms induces an immediate relative increase in home labor demand and $T O L_{t}$ no longer depreciates in the short run. Thus, the real exchange rate $\tilde{Q}_{t}$ also appreciates in the short run-in response to the appreciation of $T O L_{t}$ and the relative increase in average home import prices (which now occurs also in the short run). The opening of the economy to international asset trading does not qualitatively change the functioning of the endogenous HBS mechanism in our model. As in the case of financial autarky, the welfare-based relative price index depreciates due to the dominating effect of increased product variety at home (relative to foreign).

Figure $\mathrm{V}$ shows impulse responses to deregulation of the home market. The comparison with the case of financial autarky in Figure II is similar to what we described concerning a productivity shock. Home households borrow from abroad to front-load entry of new firms in the more favorable home market. The home country runs a current account deficit, and accumulates foreign debt. Home consumption initially declines and is permanently higher in the long run. Foreign consumption moves by more than in Figure II as foreign households initially save in the form of foreign lending and then receive income from their positive asset position. The terms of labor, $T O L_{t}$, and the real exchange rate $\tilde{Q}_{t}$ appreciate in both the short run and the long run. Again, the welfare-based relative price index $Q_{t}$ depreciates.

Dynamics in response to a productivity shock with persistence .9 are qualitatively similar to those under financial autarky; thus, we omit the figure. As in the case of a permanent shock, an important difference is the absence of an initial depreciation of the terms of labor, again motivated by faster entry of new firms into the home economy. Home households borrow initially to finance faster entry. However, borrowing is quickly reversed, and home runs current account surpluses for approximately seven years after the initial response. The path of the

42. Note that foreign lending also entails less investment in the foreign market, and a consequent larger initial drop in the number of new foreign entrants $N_{E, t}^{*}$. 

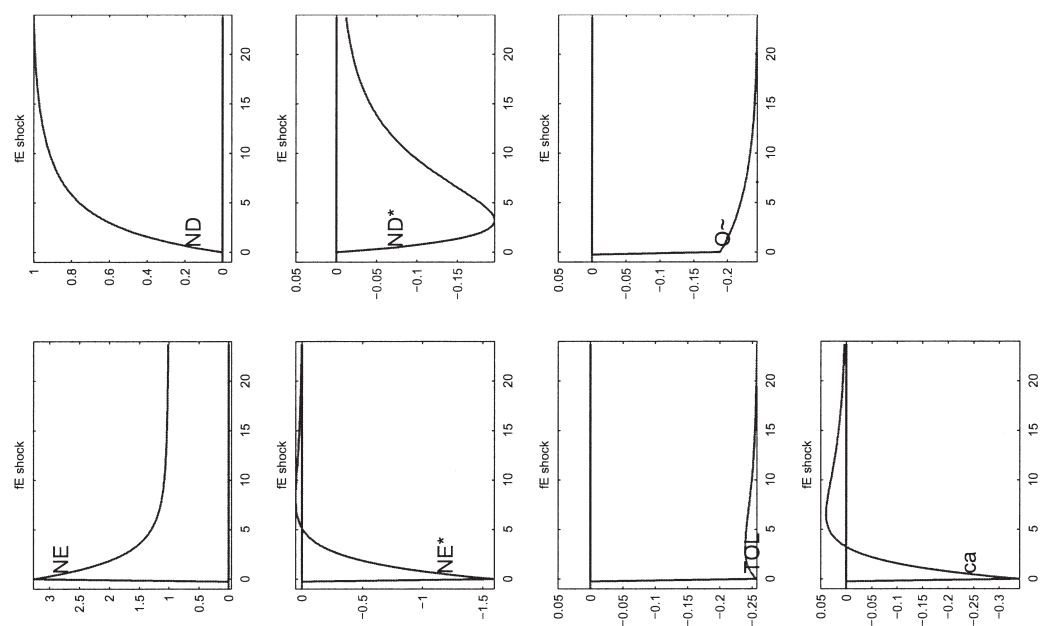

政
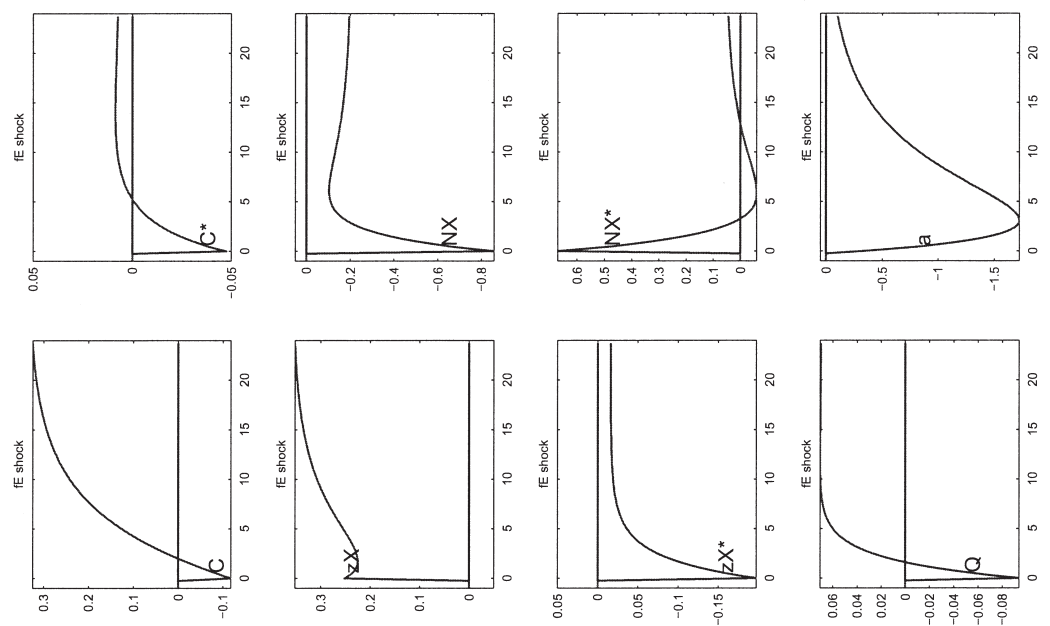
current account is such that home's net foreign assets are actually above the steady state throughout the transition, except in the initial few quarters. When the shock is not permanent, lending abroad to smooth the consequences of a temporary, favorable shock on consumption becomes the main determinant of net foreign asset dynamics.

\section{VI.B. International Business Cycles}

Backus, Kehoe, and Kydland [BKK 1992] show that introducing trade costs in an international RBC model improves its ability to replicate second moments of U.S. and international data. They specify a resource cost of trade as a quadratic function of net exports. However, the introduction of such trade costs in their model does not resolve the counterfactual prediction that consumption is more strongly correlated across countries than aggregate output (the consumption-output anomaly). Backus and Smith [1993] show that international RBC models with complete asset markets tie the cross-country consumption differential to the real exchange rate through international risk sharing. Contrary to this prediction of perfect positive correlation between relative consumption and the real exchange rate, they document that no clear pattern emerges from the data (the consumptionreal exchange rate anomaly). Chari, Kehoe, and McGrattan [CKM 2002] report evidence of negative correlation between relative consumption and the real exchange rate for the United States relative to Europe. Their sticky-price model does better than BKK concerning the consumption-output anomaly but does not resolve the consumption-real exchange rate anomaly (and also does not generate the empirical persistence of the latter). Obstfeld and Rogoff [2001] argue that introducing iceberg trade costs helps explain a variety of puzzles in international comovements, including the BKK consumption-output anomaly. They observe that trade costs and incomplete asset markets can explain the consumption-real exchange rate anomaly. ${ }^{43}$ Our model features trade costs and incomplete asset markets. Here, we investigate its ability to reproduce key features of international business cycles-including the resolution of the puzzles highlighted above.

The model includes only one source of fluctuations at busi-

43. Benigno and Thoenissen [2003] show that international asset market incompleteness plays a central role in dealing with the Backus-Smith puzzle in a model in which intermediate goods are traded and households consume only nontraded goods. 
ness cycle frequency, the shocks to aggregate productivities $Z_{t}$ and $Z_{t}^{*}$. In this section we assume that the percentage deviations of $Z_{t}$ and $Z_{t}^{*}$ from the steady state follow the bivariate process:

$$
\left[\begin{array}{c}
Z_{t} \\
Z_{t}^{*}
\end{array}\right]=\left[\begin{array}{cc}
\phi_{Z} & \phi_{Z Z^{*}} \\
\phi_{Z^{*} Z} & \phi_{Z^{*}}
\end{array}\right]\left[\begin{array}{c}
Z_{t-1} \\
Z_{t-1}^{*}
\end{array}\right]+\left[\begin{array}{c}
\xi_{t}^{Z} \\
\xi_{t}^{Z^{*}}
\end{array}\right],
$$

where the persistence parameters $\phi_{Z}$ and $\phi_{Z^{*}}$ are in the unit interval, the spillover parameters $\phi_{Z Z^{*}}$ and $\phi_{Z^{*} Z}$ are nonnegative, and $\xi_{t}^{Z}$ and $\xi_{t}^{Z^{*}}$ are normally distributed, zero-mean innovations. For purposes of comparison, we use the symmetrized estimate of the bivariate productivity process for the United States and an aggregate of European economies in BKK and set

$$
\left[\begin{array}{cc}
\phi_{Z} & \phi_{Z Z^{*}} \\
\phi_{Z^{*} Z} & \phi_{Z^{*}}
\end{array}\right]=\left[\begin{array}{cc}
.906 & .088 \\
.088 & .906
\end{array}\right] .
$$

This matrix implies a small, positive productivity spillover across countries, such that, if home productivity rises during period $t$, foreign productivity will also increase at $t+1$. We set the standard deviation of the productivity innovations to .00852 (a .73 percent variance) and the correlation to .258 (corresponding to a .19 percent covariance), as estimated by BKK. We calculate the implied second moments of endogenous variables (percent deviations from steady state) using the frequency domain technique described in Uhlig [1999], and we compare the model-generated moments with those of U. S. and international data computed in BKK and reported in Table II for the reader's convenience. ${ }^{44}$ For consistency with BKK and CKM, who focus on the high-frequency properties of business cycles in the United States and abroad, we report second moments of Hodrick-Prescott (HP)-filtered variables. ${ }^{45}$

We previously argued that empirical price deflators are best represented by the average prices $\tilde{P}_{t}$ and $\tilde{P}_{t}^{*}$ in our model (as opposed to the welfare based price indices $P_{t}$ and $P_{t}^{*}$ ). As with the real exchange rate, we thus focus on the second moments of real

44. Results based on model simulation are similar. Benigno [2004] and CKM are the sources on the empirical properties of the real exchange rate. Benigno reports averages of data in Bergin and Feenstra [2001] and CKM.

45. The productivity process has eigenvalues .994 and .818. A stationary process for productivity and model stationarity imply that all endogenous variables of interest are stationary. However, productivity and key endogenous state variables, such as the number of firms and asset stocks, are persistent enough that model-generated moments calculated without HP filtering pick up low frequency fluctuations that are not featured in the HP-filtered data in BKK. 
TABLE II

Business Cycle Data

\begin{tabular}{|c|c|c|c|c|c|c|c|c|c|c|c|}
\hline \multirow{2}{*}{\multicolumn{2}{|c|}{$\begin{array}{l}\text { United States } \\
\text { Variable }\end{array}$}} & \multicolumn{6}{|c|}{ Standard deviation } & & & & \\
\hline & & \multicolumn{3}{|c|}{ Percentage } & \multicolumn{3}{|c|}{ Relative to output } & & & & \\
\hline \multicolumn{2}{|l|}{ Output } & \multicolumn{3}{|c|}{1.71} & \multicolumn{3}{|c|}{1.00} & & & & \\
\hline \multicolumn{2}{|l|}{ Consumption } & \multicolumn{3}{|c|}{.84} & \multicolumn{3}{|c|}{.49} & & & & \\
\hline \multicolumn{2}{|l|}{ Investment } & \multicolumn{3}{|c|}{5.38} & \multicolumn{3}{|c|}{3.15} & & & & \\
\hline \multicolumn{2}{|c|}{ Capital stock } & \multicolumn{3}{|c|}{.63} & \multicolumn{3}{|c|}{.37} & & & & \\
\hline \multicolumn{2}{|c|}{ Net exports/output } & \multicolumn{3}{|c|}{.45} & & & & & & & \\
\hline \multicolumn{6}{|c|}{$\operatorname{Corr}\left(\right.$ Variable $_{t+j}$, Output $\left._{t}\right), j=-5, \ldots, 5$} & \multirow[b]{2}{*}{0} & \multirow[b]{2}{*}{1} & \multirow[b]{2}{*}{2} & \multirow[b]{2}{*}{3} & \multirow[b]{2}{*}{4} & \multirow[b]{2}{*}{5} \\
\hline Variable $\downarrow$ & -5 & -4 & -3 & -2 & -1 & & & & & & \\
\hline Output & -.03 & .15 & .38 & .63 & .85 & 1.00 & .85 & .63 & .38 & .15 & -.03 \\
\hline Consumption & .20 & .38 & .53 & .67 & .77 & .76 & .63 & .46 & .27 & .06 & -.12 \\
\hline Investment & .09 & .25 & .44 & .64 & .83 & .90 & .81 & .60 & .35 & .08 & -.14 \\
\hline $\begin{array}{l}\text { Capital } \\
\text { stock } \\
\text { Net exports/ }\end{array}$ & -.60 & -.60 & -.54 & -.43 & -.24 & .01 & .24 & .46 & .62 & .71 & .72 \\
\hline $\begin{array}{l}\text { Net exports/ } \\
\text { output }\end{array}$ & -.51 & -.51 & -.48 & -.43 & -.37 & -.28 & -.17 & .00 & .17 & .30 & .38 \\
\hline
\end{tabular}

International: Contemporaneous cross correlation

\begin{tabular}{|c|c|c|c|c|}
\hline \multirow[b]{3}{*}{ Country } & \multirow{2}{*}{\multicolumn{2}{|c|}{ with United States }} & \multicolumn{2}{|c|}{ within country } \\
\hline & & & \multirow{2}{*}{$\begin{array}{l}\text { Saving- } \\
\text { investment } \\
\text { rate }\end{array}$} & \multirow{2}{*}{$\begin{array}{l}\text { (Net exports/ } \\
\text { output)-output }\end{array}$} \\
\hline & Output & Consumption & & \\
\hline Austria & .31 & .07 & .29 & -.42 \\
\hline Finland & .02 & -.01 & .09 & -.36 \\
\hline France & .22 & -.18 & -.04 & -.17 \\
\hline Germany & .42 & .39 & .42 & -.27 \\
\hline Italy & .39 & .25 & .06 & -.62 \\
\hline Switzerland & .27 & .25 & .38 & -.66 \\
\hline United Kingdom & .48 & .43 & .07 & -.21 \\
\hline Europe & .70 & .46 & & \\
\hline United States & 1.00 & 1.00 & .68 & -.36 \\
\hline \multicolumn{5}{|c|}{ Real exchange rate } \\
\hline Source & $\begin{array}{l}\text { First-order } \\
\text { autocorr. }\end{array}$ & $\begin{array}{c}\text { Std. dev. } \\
\text { (ratio to output) }\end{array}$ & \multicolumn{2}{|c|}{$\begin{array}{l}\text { Corr. with } \\
\text { relative consumption }\end{array}$} \\
\hline CKM & .83 & 5.50 & \multirow{2}{*}{\multicolumn{2}{|c|}{-.35}} \\
\hline $\mathrm{BF}$ & .80 & 4.81 & & \\
\hline
\end{tabular}

Source: Backus, Kehoe, and Kydland [1992] unless otherwise noted. 
variables deflated by the average prices $\tilde{P}_{t}$ and $\tilde{P}_{t}^{*}$. To obtain such measures, for any variable $X_{t}$ in units of consumption, we define the corresponding real variable deflated by the average price index as $X_{R, t} \equiv P_{t} X_{t} / \tilde{P}_{t}{ }^{46}$

As we previously discussed, new entrants embody the investment by households, and the stock of firms represents the capital accumulated by such investments. For comparison with the investment and capital variables from BKK, we compute second moments for $N_{E, t}$ and $N_{D, t}$ as well as for their overall values in terms of average firm valuation deflated by the average price index $\left(\tilde{v}_{R, t}^{E}\right.$ and $\tilde{v}_{R, t}^{D}$, where $\tilde{v}_{R, t}^{E} \equiv \tilde{v}_{R, t} N_{E, t}$ and $\left.\tilde{v}_{R, t}^{D} \equiv \tilde{v}_{R, t} N_{D, t}\right)$. Consistent with BKK, we define saving (in units of consumption) as the difference between GDP and consumption, $y_{t}-C_{t}$, where GDP $y_{t}$ is defined by $y_{t} \equiv w_{t} L+N_{D, t} \tilde{d}_{D, t}$. We investigate the correlation between the saving rate $\left(1-C_{R, t} / y_{R, t}\right)$ and the investment rate $\left(\tilde{v}_{R, t}^{E} / y_{R, t}\right)$ relative to the data.

Table III reports our results. The model underpredicts the standard deviation of aggregate output (measured by GNP in BKK) and overpredicts that of consumption, although it is successful at generating less volatile consumption than GDP. The ratio of the standard deviation of $C_{R, t}$ to $y_{R, t}$ is roughly .59, ten percent higher than the consumption-output volatility ratio in BKK's data. Like fixed investment in the data, investment in new firms is substantially more volatile than GDP. The ratio of trade balance $\left(T B_{R}\right)$ to GDP is much more volatile than the net exports/ output ratio in the data. The trade costs in our model do not prevent the trade balance/GDP ratio from being quite volatile as the BKK specification does by penalizing trade balance movements directly. ${ }^{47}$ Instead, the real exchange rate is clearly less volatile than in the data. There, it reflects to a large extent the volatility of the nominal exchange rate, which has no impact on real variables in the flexible-price setup of this paper.

The model is quite successful at reproducing the autocorrelation function of key U. S. aggregate variables with output: the autocorrelation functions for output itself, consumption, investment in new firms, the stock of productive firms, and the trade balance in Table III all reproduce the qualitative pattern in Table II. In the cases of output, consumption, and investment,

46. Unless noted, the main results are unaffected when we consider second moments of variables including the variety effect.

47. Note, however, that the volatility of the trade balance itself is much smaller. 
TABLE III

Model Generated Moments

\begin{tabular}{lrr}
\hline \hline \multicolumn{2}{l}{ Standard deviation } \\
\cline { 1 - 2 } Variable & Percentage & Relative to $y_{R}$ \\
\hline$y_{R}$ & .7950 & 1.00 \\
$C_{R}$ & .4681 & .5888 \\
$\tilde{v}_{R}^{E}$ & 3.5002 & 4.5754 \\
$N_{E}$ & 3.6314 & \\
$\tilde{v}_{R}^{D}$ & .3795 & .4773 \\
$N_{D}$ & .2697 & \\
$T B_{R} / y_{R}$ & 1.0178 & \\
$T B_{R}$ & .2968 & .3733 \\
$\tilde{Q}$ & .0278 & .035 \\
\hline \hline
\end{tabular}

$\operatorname{Corr}\left(\operatorname{Variable}_{t+j}, y_{R, t}\right), j=-5, \ldots, 5$

\begin{tabular}{lrrrrrrrrrrr}
\hline Variable $\downarrow$ & -5 & -4 & -3 & -2 & -1 & 0 & 1 & 2 & 3 & 4 & 5 \\
\hline$y_{R}$ & -.02 & .10 & .27 & .47 & .71 & 1.00 & .71 & .47 & .27 & .10 & -.02 \\
$C_{R}$ & -.08 & .03 & .18 & .37 & .59 & .87 & .66 & .48 & .32 & .19 & .08 \\
$\tilde{v}_{R}^{E}$ & .08 & .18 & .31 & .46 & .65 & .86 & .49 & .22 & .02 & -.12 & -.21 \\
$N_{E}$ & .07 & .17 & .29 & .44 & .62 & .84 & .49 & .23 & .04 & -.10 & -.19 \\
$\tilde{v}_{R}^{D}$ & -.34 & -.37 & -.39 & -.39 & -.37 & -.33 & .06 & .30 & .45 & .51 & .52 \\
$N_{D}$ & -.41 & -.38 & -.31 & -.21 & -.05 & .16 & .44 & .59 & .65 & .65 & .60 \\
$T B_{R} / y_{R}$ & -.01 & -.13 & -.29 & -.48 & -.71 & -.99 & -.66 & -.41 & -.20 & -.05 & .07 \\
$T B_{R}$ & -.05 & -.13 & -.23 & -.36 & -.50 & -.67 & -.33 & -.10 & .05 & .14 & .18 \\
\hline
\end{tabular}

$\operatorname{Corr}\left(\widetilde{Q}_{t+j}, \widetilde{Q}_{t}\right), j=-5, \ldots, 5$

\begin{tabular}{rrrrrrrrrrr}
\hline-5 & -4 & -3 & -2 & -1 & 0 & 1 & 2 & 3 & 4 & 5 \\
\hline .19 & .37 & .55 & .73 & .89 & 1.00 & .89 & .73 & .55 & .37 & .19
\end{tabular}

Contemporaneous cross correlation

\begin{tabular}{lllll}
\hline$y_{R}^{*}, y_{R}$ & $C_{R}^{*}, C_{R}$ & $1-C_{R} / y_{R}, \tilde{v}_{R}^{E} / y_{R}$ & $C_{R} / C_{R}^{*}, \widetilde{Q}$ & $C / C^{*}, Q$ \\
\hline .21 & .86 & .95 & -.99 & .71
\end{tabular}

success is also reasonable, if not striking, on quantitative grounds.

The BKK model does not deliver positive correlation between home and foreign output. A puzzling negative cross-country correlation of aggregate outputs is a standard result of the international RBC literature. Our model successfully generates positive correlation between foreign and domestic GDPs. However, as the BKK setup, ours does not generate cross-country consumption 
correlation that is smaller than the correlation across GDPs for the same parameterization of productivity. The contemporaneous correlation between saving and investment rates is positive, but stronger than in the data. The autocorrelation function for the real exchange rate $\tilde{Q}_{t}$ displays substantial persistence, with a first-order coefficient equal to .89 roughly in line with the evidence. The correlation between relative consumption spending and the real exchange rate $\tilde{Q}_{t}$ is negative, as in the CKM data, but too large in absolute value. The correlation between relative consumption (including the variety effect) and the consumptionbased real exchange rate, which is 1 in Backus and Smith's [1993] complete markets world, is .71.

To verify robustness, we considered an alternative parameterization of the productivity process (6) and set $\phi_{Z Z^{*}}=\phi_{Z^{*} Z}=$ 0 and $\phi_{Z Z}=\phi_{Z^{*} Z^{*}}=.999$, consistent with evidence described in Baxter [1995] and Baxter and Farr [2005]. As in Baxter's exercise, we kept the same variance-covariance matrix of the productivity innovations as in BKK. Several key features of our results do not change in this scenario relative to the BKK productivity process. ${ }^{48}$ In particular, the model continues to perform well on the persistence dimension. The real exchange rate is somewhat less persistent, but its volatility increases. Most importantly, the consumption-output anomaly is substantially weaker. The correlation between $C_{R}$ and $C_{R}^{*}$ is only slightly larger than that between $y_{R}$ and $y_{R}^{*}$ (.46 versus .44, respectively), and the correlation between $C$ and $C^{*}$ becomes smaller than that between $y$ and $y^{*}$ (.30 versus .32, respectively). When productivity spillovers are present, the response of foreign consumption to a home shock is larger, as foreign households anticipate that foreign productivity will rise too. When we remove the spillovers, the increase in foreign consumption following a home shock is muted, significantly ameliorating the anomaly. The correlation between saving and investment rates is now in the same range as in the data (.47). As in the case of the BKK productivity process, the correlation between $C_{R} / C_{R}^{*}$ and $\tilde{Q}$ is negative, but too large in absolute value (-.98). Importantly, the correlation between $C / C^{*}$ and $Q$ now drops to $.13 .{ }^{49}$

Overall, we interpret the results of the stochastic exercise of

48. We omit details, but they are available on request.

49. Setting the scale parameter for the costs of adjusting bond holdings to .01 leaves most results unaffected. 
this section as supportive of the novel features of our model as a mechanism for the propagation of business cycles across countries and over time. Even after HP filtering (and thus removing low-frequency fluctuations that are arguably important for medium- to long-run transmission), the model is successful at generating persistent dynamics of endogenous variables and matching several key moments of the data quite well for plausible parameter values-chosen to match micro-level data-and a standard productivity process. Consistent with Obstfeld and Rogoff's [2001] arguments, the introduction of trade costs and market incompleteness pushes results in the right direction with respect to important puzzles in international macroeconomics, although assumptions about the exogenous shock process also play an important role.

\section{Conclusions}

We developed a two-country, stochastic, general equilibrium model of international trade and macroeconomic dynamics. Relative to existing international macro models, ours has the advantage of matching several features of empirical evidence in the micro, trade literature. It does so while preserving substantial tractability and the ability to provide intuitions for the main results.

We assumed that firms face some uncertainty about their future productivity when they make the decision whether or not to sink the resources necessary to enter the domestic market. Consistent with overwhelming empirical evidence, we assumed that firms face fixed costs as well as per-unit costs when they export. As a consequence of the fixed export cost, only the relatively more productive firms self-select into the export market. Aggregate productivity shocks, changes in domestic market regulation, and changes in trade policy cause firms to enter and exit markets and generate deviations from PPP that would not exist absent our microeconomic structure.

Our model provides a fully microfounded, endogenous explanation for the HBS effect. All goods are tradable in our setup, while some are nontraded in equilibrium: this nontradedness margin then changes over time. In contrast to the textbook treatment of the HBS effect, shocks are aggregate rather than sectorspecific. Our model predicts that more productive economies, or less regulated ones, exhibit higher average prices relative to their 
trading partners. This real exchange rate appreciation is driven by entry and endogenous nontradedness, the two key new features of our setup. Entry also has a positive effect on a country's terms of trade in response to productivity advantages. The same new features of our model result in substantial persistence of key endogenous variables in response to transitory exogenous shocks. In particular, our model results in persistent PPP deviations in a world of flexible prices.

When we allow for international borrowing and lending, the model predicts that more productive, or less regulated, economies will experience HBS real appreciation and run persistent foreign debt positions to finance faster entry of new firms in the economy. Thus, our framework provides a novel perspective on recent stylized facts for the U. S. economy that are broadly in line with these predictions. In addition, the model matches several important moments of the U.S. and international business cycle quite well for reasonable assumptions about parameters and productivity. In particular, it generates positive GDP correlation across countries, it does not constrain the correlation between relative consumption and the real exchange rate to being perfect, and it improves on the standard international RBC setup as far as cross-country correlations of consumption and GDP are concerned, confirming Obstfeld and Rogoff's [2001] argument that trade costs help explain international macroeconomic puzzles.

Importantly, our model suggests a dichotomy between the behavior of relative CPIs as currently measured by the data and a welfare-based measure of the real exchange rate that accounts for availability of new varieties. Rather than appreciating, the latter depreciates as a consequence of a productivity advantage or deregulation. This raises the issue of PPP adjustments in international statistics, which may contain substantial biases due to the omission of variety effects. The policy relevance of this implication is apparent, since international agencies use these PPP adjustments to compare per capita income levels that determine crucial international policy decisions such as the allocation of aid.

\section{Appendix 1: Trade Policy}

In this Appendix we investigate the effects of changes in exogenous trade costs. We focus on the consequences of trade liberalization: a symmetric, worldwide decrease in the iceberg $\operatorname{costs} \tau_{t}=\tau_{t}^{*}$ or fixed export costs $f_{X, t}=f_{X, t}^{*}$. The impulse 

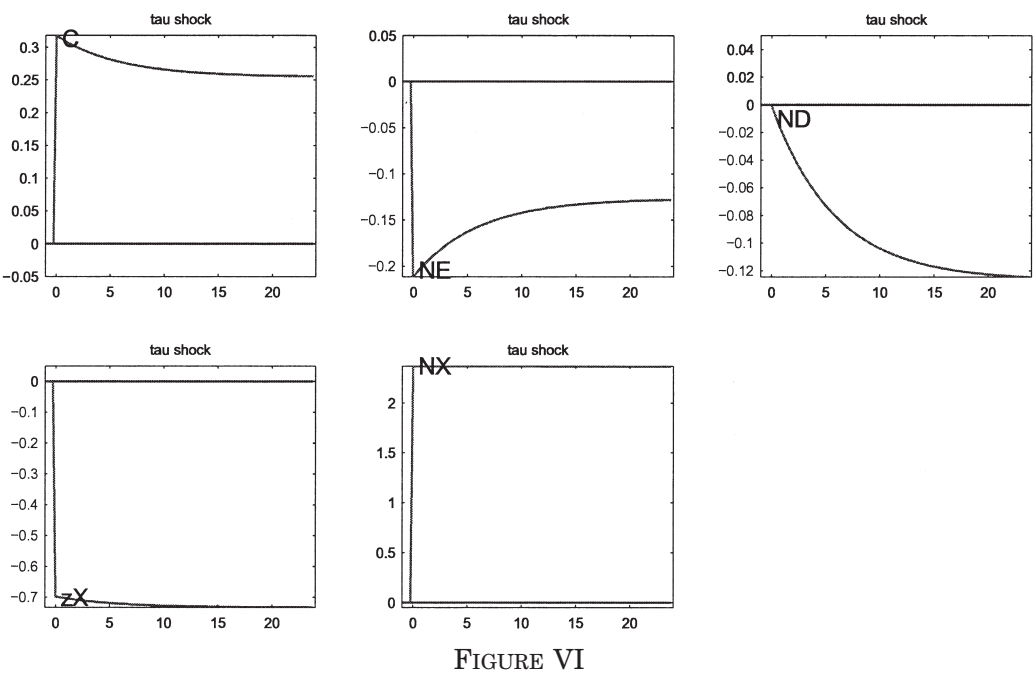

Response to Permanent $\tau=\tau^{*}$ Shock

responses are in Figures VI and VII. Since the shocks are symmetric, there are no movements in relative, cross-country variables such as the terms of labor, the terms of trade, and the real
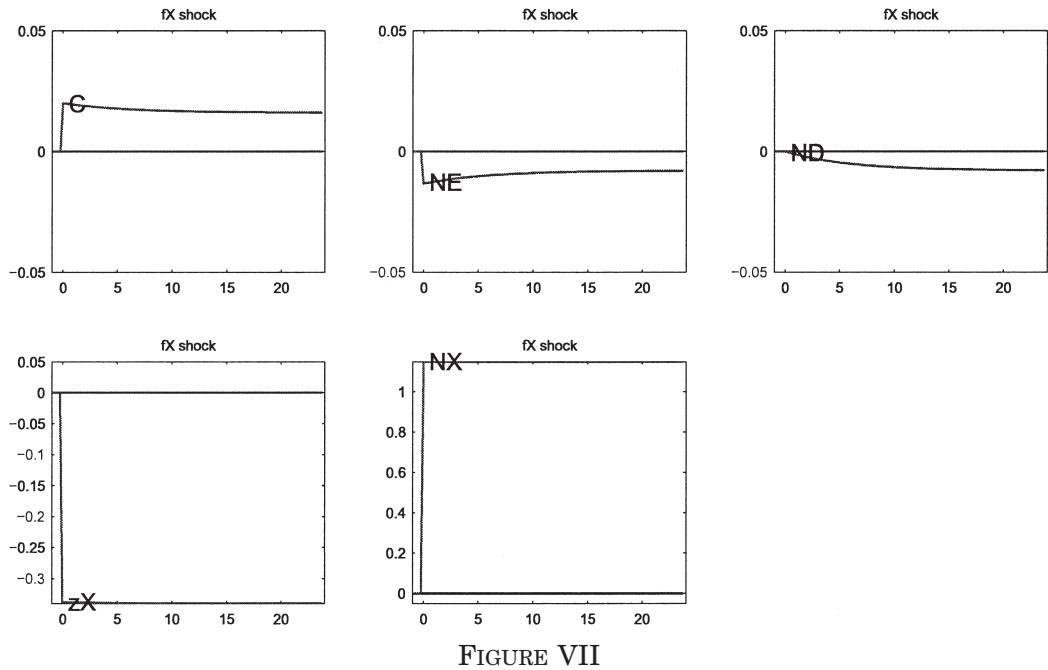

Response to Permanent $f_{x}=f_{x}^{*}$ Shock 
exchange rate. Thus, only home variables are represented, as the responses of all foreign variables are identical to their home counterparts. In both scenarios, trade liberalization induces a substantial increase in the number of exporting firms, along with a decrease in the export productivity cutoff (exporting becomes more profitable for all firms). The increased export competition induces a small downward adjustment in the number of domestic firms. However, product variety $N_{t}=N_{D, t}+N_{X, t}$ increases in both countries as the increase in the number of exporters dominates this small reduction in the number of domestic firms. ${ }^{50}$ As expected, the welfare gains from a decrease in the iceberg cost (which affects the trade costs for all export production) are greater than those generated from a decrease in fixed cost (which does not affect any marginal trade costs). As documented in many micro-level studies of trade liberalization, our simulation results highlight the feature that a substantial portion of the increase in overall trade comes from the extensive margin (more exporting firms).

\section{Appendix 2: International Bond Trading}

The budget constraint of the representative home household, in units of the home consumption basket, is now

$$
\begin{aligned}
& B_{t+1}+Q_{t} B_{*, t+1}+\frac{\eta}{2}\left(B_{t+1}\right)^{2}+\frac{\eta}{2} Q_{t}\left(B_{*, t+1}\right)^{2}+\tilde{v}_{t} N_{H, t} x_{t+1}+C_{t} \\
& =\left(1+r_{t}\right) B_{t}+Q_{t}\left(1+r_{t}^{*}\right) B_{*, t}+\left(\tilde{d}_{t}+\tilde{v}_{t}\right) N_{D, t} x_{t}+T_{t}^{f}+w_{t} L,
\end{aligned}
$$

where $B_{t+1}$ denotes holdings of home bonds, $B_{*, t+1}$ denotes holdings of foreign bonds, $(\eta / 2)\left(B_{t+1}\right)^{2}$ is the cost of adjusting holdings of home bonds, $(\eta / 2)\left(B_{*, t+1}\right)^{2}$ is the cost of adjusting holdings of foreign bonds (in units of foreign consumption), $T_{t}^{f}$ is the fee rebate, taken as given by the household, and equal to $(\eta / 2)\left[\left(B_{t+1}\right)^{2}+Q_{t}\left(B_{*, t+1}\right)^{2}\right]$ in equilibrium. For simplicity, we assume that the scale parameter $\eta>0$ is identical across costs of adjusting holdings of home and foreign bonds. Also, there is no

50. To see this based on the impulse responses for $N_{D, t}$ and $N_{X, t}$, recall that the steady-state ratio of exporting firms is calibrated to the U. S. empirical share of $N_{X} / N_{D}=.21$. The impulse responses clearly show that the increase in $N_{X, t}$ is much greater than five times (1/.21) the decrease in $N_{D, t}$. 
cost of adjusting equity holdings. The justification for this is that, in equilibrium, bond holdings differ from zero only because of transactions with a foreign counterpart. As a consequence, in equilibrium, bond-adjustment fees actually capture fees on international transactions, which we assume absent from domestic transactions such as those involving equity to avoid adding unnecessary complication. ${ }^{51}$

The representative foreign household faces a similar constraint, in units of foreign consumption:

$$
\begin{aligned}
& \frac{B_{t+1}^{*}}{Q_{t}}+B_{*, t+1}^{*}+\frac{\eta}{2} \frac{\left(B_{t+1}^{*}\right)^{2}}{Q_{t}}+\frac{\eta}{2}\left(B_{*, t+1}^{*}\right)^{2}+\tilde{v}_{t}^{*} N_{F, t}^{*} x_{t+1}^{*}+C_{t}^{*} \\
= & \frac{\left(1+r_{t}\right)}{Q_{t}} B_{t}^{*}+\left(1+r_{t}^{*}\right) B_{*, t}^{*}+\left(\tilde{d}_{t}^{*}+\tilde{v}_{t}^{*}\right) N_{D, t}^{*} x_{t}^{*}+T_{t}^{f *}+w_{t}^{*} L^{*},
\end{aligned}
$$

where $B_{t+1}^{*}$ denotes holdings of the home bond, $B_{*, t+1}^{*}$ denotes holdings of the foreign bond, and $T_{t}^{f *}=(\eta / 2)\left[\left(B_{t+1}^{*}\right)^{2} / Q_{t}+\right.$ $\left(B_{*, t+1}^{*}\right)^{2}$ ] in equilibrium.

Home and foreign households maximize the respective intertemporal utility functions subject to the respective constraints. The first-order conditions for the choices of share holdings in mutual portfolios of domestic firms at home and abroad are unchanged relative to the case of financial autarky. Instead, we have the following Euler equations for bond holdings. At home,

$$
\begin{aligned}
\left(C_{t}\right)^{-\gamma}\left(1+\eta B_{t+1}\right) & =\beta\left(1+r_{t+1}\right) E_{t}\left[\left(C_{t+1}\right)^{-\gamma}\right], \\
\left(C_{t}\right)^{-\gamma}\left(1+\eta B_{*, t+1}\right) & =\beta\left(1+r_{t+1}^{*}\right) E_{t}\left[\frac{Q_{t+1}}{Q_{t}}\left(C_{t+1}\right)^{-\gamma}\right] .
\end{aligned}
$$

Abroad,

$$
\begin{aligned}
\left(C_{t}^{*}\right)^{-\gamma}\left(1+\eta B_{t+1}^{*}\right) & =\beta\left(1+r_{t+1}\right) E_{t}\left[\frac{Q_{t}}{Q_{t+1}}\left(C_{t+1}^{*}\right)^{-\gamma}\right], \\
\left(C_{t}^{*}\right)^{-\gamma}\left(1+\eta B_{*, t+1}^{*}\right) & =\beta\left(1+r_{t+1}^{*}\right) E_{t}\left[\left(C_{t+1}^{*}\right)^{-\gamma}\right] .
\end{aligned}
$$

51. We also experimented with a specification of the cost of adjusting bond holdings as a function of overall assets: $\left(\eta^{\prime} / 2\right)\left(A_{t+1}\right)^{2}$, where $A_{t+1} \equiv B_{t+1}+$ $Q_{t} B_{*, t+1}$. The specification we use has the advantage of pinning down uniquely the steady-state levels and dynamics of $B_{t+1}$ and $B_{*, t+1}$ as well as of their aggregate. The alternative specification only pins down the latter. It is possible to verify that the two specifications yield identical log-linear dynamics under the assumptions that the steady-state levels of $B_{t+1}$ and $B_{*, t+1}$ are zero when the cost $\left(\eta^{\prime} / 2\right)\left(A_{t+1}\right)^{2}$ is used and $\eta^{\prime}=(1 / 2) \eta$. 
The presence of the terms that depend on the stock of bonds on the left-hand side of these equations is crucial for determinacy of the steady state and model stationarity. It ensures that zero holdings of bonds are the unique steady state in which the product of $\beta$ times the gross interest rate equals 1 in each country, so that economies return to this initial position after temporary shocks. If we had perfect foresight and $\eta=0$, Euler equations for bond holdings at home and abroad would imply the no-arbitrage condition $\left(1+r_{t+1}\right) /\left(1+r_{t+1}^{*}\right)=Q_{t+1} / Q_{t}$. This is the familiar condition that says that the real interest rate differential must be equal to expected depreciation of the consumption-based real exchange rate for agents to be indifferent between home and foreign bonds. With perfect foresight and $\eta>0$, no-arbitrage conditions for home and foreign households imply

$$
\frac{1+r_{t+1}}{1+r_{t+1}^{*}}=\frac{Q_{t+1}}{Q_{t}} \frac{1+\eta B_{t+1}}{1+\eta B_{*, t+1}}=\frac{Q_{t+1}}{Q_{t}} \frac{1+\eta B_{t+1}^{*}}{1+\eta B_{*, t+1}^{*}} .
$$

Equilibrium requires that home and foreign bonds be in zero net supply worldwide:

$$
\begin{gathered}
B_{t+1}+B_{t+1}^{*}=0, \\
B_{*, t+1}+B_{*, t+1}^{*}=0 .
\end{gathered}
$$

Home and foreign holdings of each individual bond must add up to zero because each country is populated by a unitary mass of identical households that make identical equilibrium choices, and only the home (foreign) country issues home (foreign) currency bonds. Using (8) and (9) in conjunction with the second equality in (7) makes it possible to show that $B_{t+1}=B_{*, t+1}$ and $B_{t+1}^{*}=$ $B_{*, t+1}^{*}$ at an optimum under perfect foresight. Since households face quadratic costs of adjusting bond holdings with identical scale parameters across bonds, it is optimal to adjust holdings of different bonds equally so as to spread the cost evenly. The same result holds in the log-linear version of the stochastic model.

Aggregate accounting implies the following laws of motion for net foreign assets at home and abroad:

$$
\begin{aligned}
B_{t+1}+Q_{t} B_{*, t+1}=\left(1+r_{t}\right) B_{t}+ & Q_{t}\left(1+r_{t}^{*}\right) B_{*, t} \\
& +w_{t} L+N_{D, t} \tilde{d}_{t}-N_{E, t} \tilde{t}_{t}-C_{t},
\end{aligned}
$$




$$
\begin{aligned}
\frac{B_{t+1}^{*}}{Q_{t}}+B_{*, t+1}^{*}=\frac{\left(1+r_{t}\right)}{Q_{t}} B_{t}^{*} & +\left(1+r_{t}^{*}\right) B_{*, t}^{*} \\
& +w_{t}^{*} L^{*}+N_{D, t}^{*} \tilde{d}_{t}^{*}-N_{E, t}^{*} \tilde{v}_{t}^{*}-C_{t}^{*}
\end{aligned}
$$

where holdings of individual bonds across countries are tied by the equilibrium conditions (8) and (9). Given these conditions, multiplying (11) times $Q_{t}$ and subtracting the resulting equation from (10) yields an expression for home net foreign asset accumulation as a function of interest income and of the cross-country differentials between labor income, net investment income, and consumption:

$$
\begin{gathered}
B_{t+1}+Q_{t} B_{*, t+1}=\left(1+r_{t}\right) B_{t}+Q_{t}\left(1+r_{t}^{*}\right) B_{*, t}+\frac{1}{2}\left(w_{t} L-Q_{t} w_{t}^{*} L^{*}\right) \\
+\frac{1}{2}\left(N_{D, t} \tilde{d}_{t}-N_{D, t}^{*} Q_{t} \tilde{d}_{t}^{*}\right)-\frac{1}{2}\left(N_{E, t} \tilde{v}_{t}-N_{E, t}^{*} Q_{t} \tilde{v}_{t}^{*}\right)-\frac{1}{2}\left(C_{t}-Q_{t} C_{t}^{*}\right) .
\end{gathered}
$$

Current accounts are by definition equal to the changes in aggregate bond holdings in the two countries:

$$
\begin{aligned}
C A_{t} & \equiv B_{t+1}-B_{t}+Q_{t}\left(B_{*, t+1}-B_{*, t}\right), \\
C A_{t}^{*} & \equiv \frac{B_{t+1}^{*}-B_{t}^{*}}{Q_{t}}+B_{*, t+1}^{*}-B_{*, t}^{*} .
\end{aligned}
$$

It is straightforward to verify that the bond-market clearing conditions (8) and (9) imply that $C A_{t}+Q_{t} C A_{t}^{*}=0$ (a country's borrowing must equal the other country's lending) and $C_{t}+$ $Q_{t} C_{t}^{*}=w_{t} L+Q_{t} w_{t}^{*} L^{*}+N_{D, t} \tilde{d}_{t}+N_{D, t}^{*} Q_{t} \tilde{d}_{t}^{*}-\left(N_{E, t} \tilde{v}_{t}+\right.$ $N_{E, t}^{*} Q_{t} \tilde{v}_{t}^{*}$ ) (since the world as a whole is a closed economy, world consumption must equal world labor income plus world net investment income). quire

Labor market clearing conditions at home and abroad re-

$$
\begin{aligned}
L & =\frac{\theta-1}{w_{t}}\left(N_{D, t} \tilde{d}_{D, t}+N_{X, t} \tilde{d}_{X, t}\right)+\frac{1}{Z_{t}}\left(\theta N_{X, t} f_{X, t}+N_{E, t} f_{E, t}\right), \\
L^{*} & =\frac{\theta-1}{w_{t}^{*}}\left(N_{D, t}^{*} \tilde{d}_{D, t}^{*}+N_{X, t}^{*} \tilde{d}_{X, t}^{*}\right)+\frac{1}{Z_{t}^{*}}\left(\theta N_{X, t}^{*} f_{X, t}^{*}+N_{E, t}^{*} f_{E, t}^{*}\right) .
\end{aligned}
$$

We thus have 23 endogenous variables: $w_{t}, w_{t}^{*}, \tilde{d}_{t}, \tilde{d}_{t}^{*}, N_{E, t}$, $N_{E, t}^{*}, \tilde{z}_{X, t}, \tilde{z}_{X, t}^{*}, N_{D, t}, N_{D, t}^{*}, N_{X, t}, N_{X, t}^{*}, r_{t}, r_{t}^{*}, \tilde{v}_{t}, \tilde{v}_{t}^{*}, C_{t}, C_{t}^{*}, Q_{t}$, 
TABLE IV

Model Summary-Bond Trading

\begin{tabular}{ll}
\hline \hline & $\left(C_{t}\right)^{-\gamma}\left(1+\eta B_{t+1}\right)=\beta\left(1+r_{t+1}\right) E_{t}\left[\left(C_{t+1}\right)^{-\gamma}\right]$ \\
& $\left(C_{t}\right)^{-\gamma}\left(1+\eta B_{*, t+1}\right)=\beta\left(1+r_{t+1}^{*}\right) E_{t}\left[\frac{Q_{t+1}}{Q_{t}}\left(C_{t+1}\right)^{-\gamma}\right]$ \\
& $\left(C_{t}^{*}\right)^{-\gamma}\left(1+\eta B_{t+1}^{*}\right)=\beta\left(1+r_{t+1}\right) E_{t}\left[\frac{Q_{t}}{Q_{t+1}}\left(C_{t+1}^{*}\right)^{-\gamma}\right]$ \\
& $\left(C_{t}^{*}\right)^{-\gamma}\left(1+\eta B_{*, t+1}^{*}\right)=\beta\left(1+r_{t+1}^{*}\right) E_{t}\left[\left(C_{t+1}^{*}\right)^{-\gamma}\right]$ \\
& $B_{t+1}+Q_{t} B_{*, t+1}=\left(1+r_{t}\right) B_{t}+Q_{t}\left(1+r_{t}^{*}\right) B_{*, t}$ \\
& $+1 / 2\left(w_{t} L-Q_{t} w_{t}^{*} L^{*}\right)+1 / 2\left(N_{D, t} \tilde{d}_{D, t}\right.$ \\
& $\left.-N_{D, t}^{*} Q_{t} \tilde{d}_{D, t}^{*}\right)+1 / 2\left(N_{X, t} \tilde{d}_{X, t}-N_{X, t}^{*} Q_{t} \tilde{d}_{X, t}^{*}\right)$ \\
Net foreign assets & $-1 / 2\left(N_{E, t} \tilde{v}_{t}-N_{E, t}^{*} Q_{t} \tilde{v}_{t}^{*}\right)-1 / 2\left(C_{t}-Q_{t} C_{t}^{*}\right)$ \\
& $B_{t+1}+B_{t+1}^{*}=0$ \\
& $B_{*, t+1}^{*} B_{*, t+1}^{*}=0$ \\
Bond market & $L=\frac{\theta-1}{w_{t}}\left(N_{D, t} \tilde{d}_{D, t}+N_{X, t} \tilde{d}_{X, t}\right)+\frac{1}{Z_{t}}\left(\theta N_{X, t} f_{X, t}+N_{E, t} f_{E, t}\right)$ \\
Labor market & $L^{*}=\frac{\theta-1}{w_{t}^{*}}\left(N_{D, t}^{*} \tilde{d}_{D, t}^{*}+N_{X, t}^{*} \tilde{d}_{X, t}^{*}\right)+\frac{1}{Z_{t}^{*}}\left(\theta N_{X, t}^{*} f_{X, t}^{*}+N_{E, t}^{*} f_{E, t}^{*}\right)$
\end{tabular}

$B_{t}, B_{*, t}, B_{t}^{*}, B_{*, t}^{*}$. Of these, eight are predetermined as of time $t$ : the total numbers of firms at home and abroad, $N_{D, t}$ and $N_{D, t}^{*}$, the risk-free interest rates, $r_{t}$ and $r_{t}^{*}$, and the stocks of bonds, $B_{t}$, $B_{*, t}, B_{t}^{*}$, and $B_{*, t}^{*}$. The model features the same eight exogenous variables as in the financial autarky case. The 23 endogenous variables above are determined by a system of 23 equations that is identical to the system in Table I in the following blocks: Price indexes, Profits, Free entry, Zero-profit export cutoffs, Share of exporting firms, Number of firms, Euler equation (shares). The five equations in Euler equation (bonds), Aggregate accounting, and Balanced trade are replaced by the nine equations in Table IV. ${ }^{52}$

Boston College and Euro Area Business Cycle Network

Harvard University, Centre for Economic Policy Research, and National

BUREAU OF ECONOMIC RESEARCH

52. Of course, we apply again the functions at the bottom of Table I. 


\section{REFERENCES}

Alessandria, George, and Horag Choi, "Export Decisions and International Business Cycles," mimeo, Ohio State University, 2003.

Backus, David K., Patrick J. Kehoe, and Finn E. Kydland, "International Real Business Cycles," Journal of Political Economy, C (1992), 745-775.

Backus, David K., and Gregor W. Smith, "Consumption and Real Exchange Rates in Dynamic Economies with Non-Traded Goods," Journal of International Economics, XXXV (1993), 297-316.

Baldwin, Richard E., and Richard K. Lyons, "Exchange Rate Hysteresis? Large Versus Small Policy Misalignments," European Economic Review, XXXVIII (1994), 1-22.

Baxter, Marianne, "International Trade and Business Cycles," Handbook of International Economics, Gene M. Grossman and Kenneth S. Rogoff, eds., Vol. III (New York, NY: North-Holland, 1995), pp. 1801-1864.

Baxter, Marianne, and Dorsey D. Farr, "Variable Capital Utilization and International Business Cycles," Journal of International Economics, LXV (2005), 335-347.

Benigno, Gianluca, "Real Exchange Rate Persistence with Endogenous Monetary Policy," Journal of Monetary Economics, LI (2004), 473-502.

Benigno, Gianluca, and Christophe Thoenissen, "On the Consumption-Real Exchange Rate Anomaly," mimeo, London School of Economics, 2003.

Bergin, Paul R., and Robert C. Feenstra, "Pricing to Market, Staggered Contracts, and Real Exchange Rate Persistence," Journal of International Economics, LIV (2001), 333-359.

Bergin, Paul R., and Reuven Glick, "A Model of Endogenous Nontradability and Its Implications for the Current Account," mimeo, University of California, Davis, 2003a.

Bergin, Paul R., and Reuven Glick, "Endogenous Nontradability and Macroeconomic Implications," NBER Working Paper No. 9739, 2003b.

Bergin, Paul R., Reuven Glick, and Alan Taylor, "Productivity, Tradability, and the Great Divergence," mimeo, University of California, Davis, 2003.

Bernard, Andrew B., Jonathan Eaton, J. Bradford Jensen, and Samuel Kortum, "Plants and Productivity in International Trade," American Economic Review, XCIII (2003), 1268-1290.

Bernard, Andrew B., and J. Bradford Jensen, "Why Some Firms Export," NBER Working Paper No. 8349, 2001.

Bernard, Andrew B., and J. Bradford Jensen, "Entry, Expansion, and Intensity in the U. S. Export Boom, 1987-1992," Review of International Economics, XII (2004), 662-675.

Bernard, Andrew B., and Joachim Wagner, "Export Entry and Exit by German Firms," Weltwirtschaftliches Archiv-Review of World Economics, CXXXVII (2001), 105-123.

Betts, Caroline M., and Timothy J. Kehoe, "Tradability of Goods and Real Exchange Rate Fluctuations," mimeo, University of Minnesota, 2001.

Bils, Mark, and Peter J. Klenow, "The Acceleration in Variety Growth," American Economic Review, XCI (2001), 274-280.

Blanchard, Olivier J., and Francesco Giavazzi, "Macroeconomic Effects of Regulation and Deregulation in Goods and Labor Markets," Quarterly Journal of Economics, CXVIII (2003), 879-907.

Broda, Christian, and David E. Weinstein, "Globalization and the Gains from Variety," mimeo, Federal Reserve Bank of New York, 2003.

Burstein, Ariel T., Martin Eichenbaum, and Sergio Rebelo, "Why Are Rates of Inflation So Low After Large Devaluations?” NBER Working Paper No. 8748, 2002.

Burstein, Ariel T., João C. Neves, and Sergio Rebelo, "Distribution Costs and Real Exchange Rate Dynamics during Exchange-Rate-Based Stabilizations," Journal of Monetary Economics, L (2003), 1189-1214.

Caballero, Ricardo J., and Mohamad L. Hammour, "The Cleansing Effect of Recessions," American Economic Review, LXXXIV (1994), 1350-1368.

Campbell, Jeffrey R., "Entry, Exit, Embodied Technology, and Business Cycles," Review of Economic Dynamics, I (1998), 371-408. 
Chari, Varadarajan V., Patrick J. Kehoe, and Ellen R. McGrattan, "Can Sticky Price Models Generate Volatile and Persistent Real Exchange Rates?" Review of Economic Studies, LXIX (2002), 533-563.

Cheung, Yin-Wong, Menzie D. Chinn, and Eiji Fujii, "Market Structure and the Persistence of Sectoral Real Exchange Rates," International Journal of Finance and Economics, VI (2001), 95-114.

Corsetti, Giancarlo, and Luca Dedola, "A Macroeconomic Model of International Price Discrimination," Journal of International Economics, forthcoming.

Corsetti, Giancarlo, Luca Dedola, and Sylvain Leduc, "International Risk-Sharing and the Transmission of Productivity Shocks," European Central Bank Working Paper No. 308, 2004.

Corsetti, Giancarlo, Philippe Martin, and Paolo Pesenti, "Productivity Spillovers, Terms of Trade, and the 'Home Market Effect'," NBER Working Paper No. $11165,2005$.

Das, Sanghamitra, Mark J. Roberts, and James R. Tybout, "Market Entry Costs, Producer Heterogeneity and Export Dynamics," NBER Working Paper No. $8629,2001$.

Dornbusch, Rudiger, Stanley Fischer, and Paul A. Samuelson, "Comparative Advantage, Trade, and Payments in a Ricardian Model with a Continuum of Goods," American Economic Review, LXVII (1977), 823-839.

Dumas, Bernard, "Dynamic Equilibrium and the Real Exchange Rate in a Spatially Separated World," Review of Financial Studies, V (1992), 153-180.

Engel, Charles, "Real Exchange Rates and Relative Prices: An Empirical Investigation," Journal of Monetary Economics, XXXII (1993), 35-50.

_- "Accounting for U. S. Real Exchange Rate Changes," Journal of Political Economy, CVII (1999), 507-538.

Feenstra, Robert C., "New Product Varieties and the Measurement of International Prices," American Economic Review, LXXXIV (1994), 157-177.

Fitzgerald, Doireann, "Terms-of-Trade Effects, Interdependence and Cross-Country Differences in Price Levels," mimeo, University of California, Santa Cruz, 2003.

Gagnon, Joseph E., "Productive Capacity, Product Varieties, and the Elasticities Approach to the Trade Balance," Board of Governors of the Federal Reserve System, International Finance Discussion Paper No. 781, 2003.

Ghironi, Fabio, "Macroeconomic Interdependence under Incomplete Markets," Boston College Economics Working Paper No. 471, 2000.

Imbs, Jean, Haroon Mumtaz, Morten O. Ravn, and Hélène Rey, "PPP Strikes Back: Aggregation and the Real Exchange Rate," Quarterly Journal of Economics, CXX (2005), 1-43.

Kehoe, Timothy J., and Kim J. Ruhl, "How Important Is the New Goods Margin in International Trade?" mimeo, University of Minnesota, 2002.

Kraay, Aart, and Jaume Ventura, "Trade Integration and Risk Sharing," European Economic Review, XLVI (2002), 1023-1048.

Krugman, Paul, "Differences in Income Elasticities and Trends in Real Exchange Rates," European Economic Review, XXXIII (1989), 1055-1085.

Lane, Philip R., "The New Open Economy Macroeconomics: A Survey," Journal of International Economics, LIV (2001), 235-266.

MacDonald, Ronald, and Luca A. Ricci, "Purchasing Power Parity and New Trade Theory," International Monetary Fund Working Paper No. 02/32, 2002.

Melitz, Marc J., "The Impact of Trade on Intra-Industry Reallocations and Aggregate Industry Productivity," Econometrica, LXXI (2003), 1695-1725.

Obstfeld, Maurice, and Kenneth S. Rogoff, Foundations of International Macroeconomics (Cambridge, MA: MIT Press, 1996).

Obstfeld, Maurice, and Kenneth S. Rogoff, "The Six Major Puzzles in International Macroeconomics: Is There a Common Cause?" NBER Macroeconomics Annual 2000, Ben S. Bernanke and Kenneth S. Rogoff, eds. (Cambridge, MA: MIT Press, 2001), pp. 339-390.

Ricci, Luca A., "Exchange Rate Regimes and Location," International Monetary Fund Working Paper No. 97/69, 1997.

Roberts, Mark J., and James R. Tybout, "The Decision to Export in Colombia: An Empirical Model of Entry with Sunk Costs," American Economic Review, LXXXVII (1997), 545-564. 
Rogoff, Kenneth S., "The Purchasing Power Parity Puzzle," Journal of Economic Literature, XXXIV (1996), 647-668.

Rotemberg, Julio J., and Michael Woodford, "Oligopolistic Pricing and the Effects of Aggregate Demand on Economic Activity," Journal of Political Economy, C (1992), 1153-1207.

Ruhl, Kim J., "Solving the Elasticity Puzzle in International Economics," mimeo, University of Minnesota, 2003.

Russ, Katheryn N., "The Endogeneity of the Exchange Rate as a Determinant of FDI: A Model of Money, Entry, and Multinational Firms," mimeo, Johns Hopkins University, 2003.

Uhlig, Harald, "A Toolkit for Analyzing Nonlinear Dynamic Stochastic Models Easily," Computational Methods for the Study of Dynamic Economies, Ramon Marimon and Andrew Scott, eds. (Oxford, UK: Oxford University Press, 1999), pp. $30-61$.

Woodford, Michael, Interest and Prices: Foundations of a Theory of Monetary Policy (Princeton, NJ: Princeton University Press, 2003). 